\title{
Inwigilacja i proces kierownictwa Zarządu Okręgowego Państwowych Nieruchomości Ziemskich w Olsztynie
}

\begin{abstract}
Abstrakt: W artykule przedstawiono proces usuwania ziemian ze stanowisk kierowniczych w Zarządzie Okręgowym Państwowych Nieruchomości Ziemskich w Olsztynie. Na podstawie analizy akt wytworzonych przez Wojewódzki Urząd Bezpieczeństwa Publicznego w Olsztynie oraz akt procesowych Sądu Apelacyjnego w Olsztynie wykazano rolę funkcjonariuszy Urzędu Bezpieczeństwa Publicznego, a także dyspozycyjnych prokuratorów oraz sędziów w przygotowaniu procesów pokazowych i skazaniu kierownictwa przedsiębiorstwa na bardzo surowe kary, w tym dyrektora na karę śmierci.
\end{abstract}

Słow a kluczowe: Państwowe Nieruchomości Ziemskie, rolnictwo, stalinizm, sądownictwo, ziemianie.

Abstract: The article presents a process of ousting landowners from managerial posts in the Regional Department of the State Land Properties in Olsztyn. Upon an analysis of documents generated by the Voivode Office of Public Security in Olsztyn and procedural documents of the Appellate Court in Olsztyn a role played by functionaries of the Public Security Office was revealed, together with that of prosecutors and judges in preparations for show trials and conviction with severe punishment, including the death penalty.

Key w or d s: State Land Properties, agriculture, Stalinism, judiciary, landowners.

\section{Powstanie i cele działalności Państwowych Nieruchomości Ziemskich}

$\mathrm{Na}$ ziemiach włączonych do Polski po II wojnie światowej poniemieckie majatki ziemskie, w niemałej liczbie przejęte początkowo przez wojska sowieckie, 
stopniowo i z oporem przekazywane były polskiej administracji rolnej ${ }^{1}$. Zgodnie z zapisami dekretu o przeprowadzeniu reformy rolnej folwarki przekraczajace 100 ha powierzchni ogólnej przejmował Państwowy Fundusz Ziemi (PFZ). W części miały być wykorzystane na upełnorolnienie gospodarstw karłowatych i tworzenie nowych, w części włączone do zapasu ziemi PFZ, którym $\mathrm{w}$ imieniu ministra rolnictwa i reform rolnych dysponowały urzędy ziemskie. Wyłączenie części gruntów spod parcelacji i pozostawienie ich w państwowej domenie służyć winno tworzeniu m.in. „wzorowych gospodarstw w interesie podniesienia poziomu gospodarki rolnej”’. Obszar gruntów, które pozostać miały w państwowej administracji na ziemiach włączonych, ustalono na $10 \%$ ogólnej powierzchni gruntów rolnych ${ }^{3}$.

Administrowanie nieruchomościami ziemskimi przysparzało urzędom ziemskim ogromnych problemów. Do największych z nich należały kłopoty $\mathrm{w}$ relacjach z sowieckimi wojskami, które nie wywiązywały się z zapisów umów dotyczących użytkowania majątków ziemskich, opóźniały ich zwalnianie, a niejednokrotnie ponownie obejmowały folwarki zwolnione wcześniej bądź pustoszyły je z dóbr, które w nich ocalały ${ }^{4}$. Poza tym mnogość innych zadań postawionych w tym czasie przed urzędami ziemskimi (przypomnijmy chociażby o realizacji reformy rolnej, koordynowaniu akcji osadniczej, pomocy $\mathrm{w}$ uruchamianiu gospodarstw indywidualnych, wsparciu akcji rolnych) sprawiła, że administracją i zagospodarowaniem majątków państwowych zajmowało się niewielu pracowników szczebla wojewódzkiego i powiatowego. Prowadziło to do postępującej w szybkim tempie dekapitalizacji opuszczonych poniemieckich folwarków. W Ministerstwie Rolnictwa i Reform Rolnych (MRiRR) w końcu 1945 r. zaczęła dojrzewać myśl o powołaniu odrębnego

${ }^{1}$ Pierwsze majątki polska administracja przejęła już wiosną i latem 1945 r. Jednak właściwy proces przejmowania rozpoczął się dopiero po podpisaniu umowy 8 X 1945 r. Zob. Archiwum Państwowe w Olsztynie (dalej: APO), Urząd Wojewódzki (dalej: UW), 391/2124, Umowa z 8 X 1945 r. między zastępcą dowódcy Północnej Grupy Wojsk Armii Czerwonej gen. lejt. Fieofanem Łagunowem i wicepremierem Stanisławem Mikołajczykiem, k. $13-15$.

${ }^{2}$ Dekret z 6 IX 1944 r. o przeprowadzeniu reformy rolnej (tekst jednolity z dn. 18 I 1945 r.), Dz.U. 1945, nr 3, poz. 13, art. 15.

${ }^{3}$ Wielkość tę określono dopiero w połowie 1946 r. Zob. Okólnik Nr 10 z 5 VI 1946 r. w sprawie osadnictwa na ziemiach odzyskanych, „Dziennik Urzędowy Ministerstwa Rolnictwa i Reform Rolnych" 1946, nr 7, poz. 91, s. 18; Dekret z dnia 6 IX 1946 r. o ustroju rolnym i osadnictwie na obszarze Ziem Odzyskanych i byłego Wolnego Miasta Gdańska, Dz.U. 1946, nr 49, poz. 79 .

${ }^{4}$ Szerzej na temat majątków ziemskich w administracji wojsk sowieckich zob. M. Golon, Majatki ziemskie na Ziemiach Odzyskanych pod radzieckq administracjq wojskowa w latach 1945-1950, w: Wtadze komunistyczne wobec Ziem Odzyskanych po II wojnie światowej, red. S. Łach, Słupsk 1997, s. 279-300; W. Gieszczyński, Majatki ziemskie na Warmii i Mazurach pod sowieckq administracja wojskowa (1945-1948), w: Między historia polityczna a społeczna, red. J. Gołota, Pułtusk-Olsztyn-Ostrołęka-Warszawa 2014, s. 287-303. 
przedsiębiorstwa, którego głównym celem miało stać się zagospodarowanie majątków ziemskich na tzw. Ziemiach Odzyskanych ${ }^{5}$.

17 I 1946 r. Witold Maringe ${ }^{6}$ otrzymał pełnomocnictwa ministra rolnictwa i reform rolnych Stanisława Mikołajczyka w zakresie tworzenia nowego przedsiębiorstwa - Zarządu Państwowych Nieruchomości Ziemskich (PNZ) $\mathrm{Na}$ jego czele stał Zarząd Centralny (ZC) powołany w Poznaniu z dyrektorem naczelnym, wspomnianym wyżej, Witoldem Maringem. Strukturę terytorialna powstającego przedsiębiorstwa tworzyło początkowo dziewięć okręgów: opolski (Opole), wrocławski (Wrocław), legnicki (Jelenia Góra), lubuski (Poznań/ Gorzów), szczeciński (Szczecin), koszaliński (Koszalin), gdański (Sopot), olsztyński (Olsztyn), wschodnio-mazurski (Giżycko) ${ }^{8}$.

16 II 1946 r. Mikołajczyk wydał zarządzenie w sprawie przekazania przez urzędy ziemskie na tzw. Ziemiach Odzyskanych majątków o powierzchni powyżej 100 ha nowo utworzonemu przedsiębiorstwu ${ }^{9}$, natomiast $11 \mathrm{IV}$ 1946 r. - zarządzenie Nr FZ/3-I-5, w myśl którego nowo powstała instytucja przejęła także majątki ziemskie na tzw. ziemiach dawnych. Podstawową różnicą w określeniu majątków podlegających przejęciu przez PNZ na ziemiach

${ }_{5}^{5}$ Już jesienią 1945 r. z inicjatywy Wojewódzkiego Pełnomocnika Akcji Siewnej w Poznaniu Witolda Maringego powołano Państwowy Zarząd Rolny Ziemi Lubuskiej, który przejął w administrację od urzędów ziemskich majątki powyżej 100 ha. Pozytywne rezultaty tego „eksperymentu” skłoniły ministra Stanisława Mikołajczyka do decyzji o wprowadzeniu zmian w organizacji administracji w majątkach państwowych na pozostałych obszarach tzw. Ziem Odzyskanych. Szerzej zob. E. Kłoczowski, Moja praca w Państwowych Nieruchomościach Ziemskich w Poznaniu (1946-1949), Poznań 1996, s. 26-29; H. Duda, Państwowe Nieruchomości Ziemskie w Opolu (1946-1949). Zarys monograficzny, Opole 2006, s. 14-16.

${ }^{6}$ Leonard Witold Stanisław Maringe (1890-1966) - ziemianin, w 1914 r. ukończył studia w Instytucie Rolniczym w Gembloux w Belgii. Od 1919 r. właściciel majątku Lenartowo. Od 1934 r. dyrektor, a później prezes Biura Ekonomicznego Organizacji Rolniczych oraz Przemysłu Rolnego w Poznaniu. Członek Zarządu Związku Rolników z Wyższym Wykształceniem. W latach 1939-1945 w konspiracji. Dyrektor Departamentu Rolnictwa w Delegaturze Rządu na Kraj. W 1945 r. Wojewódzki Pełnomocnik Akcji Siewnej w Poznaniu. Od 1946 r. dyrektor Zarządu Centralnego Państwowych Nieruchomości Ziemskich w Poznaniu. W 1949 r. wraz z innymi osobami z centrali PNZ aresztowany i oskarżony o działalność na szkodę państwa. W 1951 r. skazany na dożywocie. W 1956 zrehabilitowany, kierownik Pracowni Badań Ekonomiki i Organizacji Produkcji Rolnej PAN. Od 1957 r. doradca ministra rolnictwa. Ziemianie polscy XX wieku. Stownik biograficzny, cz. 3, red. J. Leskiewiczowa, Warszawa 1996, s. 115-116.

${ }^{7}$ Archiwum Akt Nowych (dalej: AAN), Zarząd Centralny Państwowych Nieruchomości Ziemskich (dalej: ZC PNZ), 429/34, Pełnomocnictwo Ministra Rolnictwa i Reform Rolnych z 17 I 1946 r. Nr G.M./B. Pers. M. 69/2-46, k. 3.

8 AAN, ZC PNZ, 429/45, Zarządzenie W. Maringe'a w sprawie powołania zarządów okręgowych PNZ, 3 II 1946 r., k. 14-17. Zob. też: W. Rogala, Działalność Państwowych Nieruchomości Ziemskich (1946-1949), „Rocznik Muzeum Rolnictwa w Szreniawie” 1972, t. V, s. 26-28; H. Duda, op. cit., s. 20.

9 APO, Wojewódzki Urząd Ziemski (dalej: WUZ), 618/12, Zarządzenie Ministra Rolnictwa i Reform Rolnych Nr FZ/1-I-2/12 z 16 II 1946 r., k. 72-72v. 
dawnych była dolna granica ich powierzchni, którą ustalono na 50 ha, co wynikało z zapisów dekretu o przeprowadzeniu reformy rolnej ${ }^{10}$. Na terenach tych utworzono dalszych sześć zarządów okręgowych PNZ: warszawsko-białostocki, łódzki, bydgoski, poznański, krakowski i lubelsko-rzeszowski ${ }^{11}$.

$\mathrm{Na}$ terenie Okręgu Mazurskiego, zgodnie z ustaloną strukturą PNZ, powołano dwa zarządy okręgowe: olsztyński w Olsztynie i wschodnio-mazurski w Łuczanach (Giżycku). Na początku lutego 1946 r. na Warmię i Mazury przybyli dwaj pełnomocnicy okręgowi wyznaczeni przez Witolda Maringego: inż. Władysław Czarnecki - pełnomocnik okręgowy PNZ na Okręg w Olsztynie i inż. Ludwik Bernstein - na Okręg w Łuczanach ${ }^{12}$. Do ich zadań należało zorganizowanie biur zarządów okręgowych, powołanie pełnomocników powiatowych PNZ i rozpoczęcie procesu przejmowania majątków administrowanych dotychczas przez urzędy ziemskie. Władysława Czarneckiego w marcu 1946 r. zastapił Adam Nieniewski ${ }^{13}$. Pełnomocnicy okręgowi 12 i 13 III 1946 r. uzyskali nominacje na dyrektorów zarządów okręgowych ${ }^{14}$. Odpowiadali oni za całość prac i funkcjonowanie przedsiębiorstwa na terenie okręgu.

Zadania nowego przedsiębiorstwa nie zostały jasno w formalnych aktach prawnych określone. Wydaje się, że w najpełniejszy sposób wyartykułowano je w projekcie aktu prawnego, który nie wszedł w życie. Według pierwotnych założeń przedsiębiorstwo miało być powołane na mocy dekretu Krajowej Rady Narodowej (KRN). Odpowiedni projekt został przyjęty przez Radę Ministrów 6 VI 1946 r., jednak nie był on uchwalony przez KRN. Przedsiębiorstwo więc, przez cały okres swego istnienia (1946-1949), funkcjonowało w oparciu o pełnomocnictwa i zarządzenia MRiRR. Wspomniany projekt dekretu jest

${ }_{10}$ Zob. W. Rogala, op. cit., s. 23.

${ }^{11}$ E. Kłoczowski, op. cit., s. 30-31.

12 APO, WUZ, 618/12, Zarządzenie prezesa WUZ w Olsztynie z 23 II 1945 r., k. 90.

${ }_{13}$ Adam Nieniewski (1886-1947) - ziemianin, pułkownik WP. Do 1916 r. oficer sztabowy w armii austriackiej. W 1916 zastępca sztabu w Komendzie Legionów Polskich. Po kryzysie przysięgowym szef sztabu Komendy Polskiego Korpusu Posiłkowego. Zastępca szefa Sztabu Generalnego WP (od X 1918), szef sztabu gen. J. Hallera (od 17 VI 1919). W latach 1919-1920 kolejno szef sztabu: Frontu Południowo-Zachodniego, Frontu Pomorskiego, 1 Armii, 1 Dywizji Litewsko-Białoruskiej, 7 Pułku Strzelców Konnych Wielkopolskich, IV Brygady Jazdy. W latach 1921-1928 dowódca: VII Brygady Piechoty 4 DP, piechoty dywizyjnej 10 DP w Łodzi, piechoty dywizyjnej 7 DP w Częstochowie. Podczas przewrotu majowego w 1926 r. opowiedział się po stronie rządu. W 1928 r. przeniesiony w stan spoczynku. Osiadł w majątku ziemskim w Chorzenicach k. Częstochowy. W 1940 r., po usunięciu przez Niemców, zamieszkał w Kłomnicach pod Częstochową i pracował w punkcie skupu lnu. Po wojnie uzyskał przydział do WP. Od IV do XI 1945 r. p.o. dowódcy Okręgu Wojskowego „Poznań”, następnie zwolniony ze służby czynnej. Od III 1946 do IV 1947 r. dyrektor ZO PNZ w Olsztynie. W.K. Cygan, Stownik biograficzny oficerów Legionów Polskich, t. I, Warszawa 1992, s. 77; Polski stownik biograficzny, t. XXIII, z. 1, http://www. ipsb.nina.gov.pl/a/biografia/adam-nieniewski (dostęp: 20 I 2017).

14 E. Kłoczowski, op. cit., s. 29. 
jednak cennym źródłem ze względu na umieszczony w nim zapis celów, które postawiono przedsiębiorstwu. Według nich, obok administracji stałej w państwowych ośrodkach kultury rolnej, przedsiębiorstwo przejęło w administrację przejściową nieruchomości ziemskie przeznaczone na parcelację, a także zakłady przemysłu rolnego (do czasu ich uspołecznienia) i inne nieruchomości ziemskie przeznaczone na cele, do których realizacji powołane miały być inne instytucje ${ }^{15}$. Zgodnie z przywołanymi wyżej: okólnikiem $\mathrm{nr} 10 \mathrm{MRiRR}$ z 5 VI 1946 r. oraz dekretem z 6 IX 1946 r. o ustroju rolnym i osadnictwie na obszarze Ziem Odzyskanych i byłego Wolnego Miasta Gdańska, grunty wyłączone spod parcelacji stanowić winny 10\% użytków rolnych. Innymi słowy, blisko $90 \%$ użytków rolnych w majątkach ziemskich, przejętych przez PNZ, znalazło się w ich administracji przejściowej. Wynika stąd, że nowe przedsiębiorstwo skupić się miało głównie na zagospodarowaniu zniszczonych majątków, które z czasem zostałyby przekazane innym użytkownikom, przede wszystkim parcelantom (grupom osadniczo-parcelacyjnym i spółdzielniom osadniczo-parcelacyjnym). Taki profil działalności, sprowadzający PNZ do roli przedsiębiorstwa ułatwiajacego tworzenie gospodarstw indywidualnych na parcelowanych poniemieckich majątkach ziemskich, zgodny był z programem agrarnym PSL, które opowiadało się za ograniczeniem państwowej domeny na rzecz pełnorolnych gospodarstw chłopskich ${ }^{16}$.

\section{Ziemianie w administracji majątków ziemskich}

Jeszcze przed przejęciem $\mathrm{w}$ administrację majątków ziemskich przez PNZ spora część pracowników wojewódzkich urzędów ziemskich, a także administratorów w poniemieckich folwarkach wywodziła się spośród ziemian. Nie była to wyłącznie specyfika ziem włączonych. Już pierwsze tygodnie po utworzeniu urzędów ziemskich i ogłoszeniu dekretu o reformie rolnej pokazały na tzw. ziemiach dawnych, że sporą część kadry w powoływanych urzędach ziemskich stanowili byli właściciele majątków, którzy, zdaniem

${ }^{15}$ APO, Zarząd Państwowych Nieruchomości Ziemskich. Zarząd Okręgowy w Olsztynie (dalej: ZO PNZ), 2471/4, Dekret o utworzeniu przedsiębiorstwa Państwowe Nieruchomości Ziemskie przyjęty przez Radę Ministrów 6 VI 1946 r., k. 9-10 [niezatwierdzony przez KRN i w efekcie nieogłoszony w Dzienniku Ustaw].

${ }^{16}$ Według koncepcji PSL obszar ziemi w administracji państwowej nie powinien przekraczać 2-3\% użytków rolnych, a działalność ośrodków kultury rolnej winna ograniczać się do roli usługowej wobec gospodarstw indywidualnych. Zob. Archiwum Zakładu Historii Ruchu Ludowego (dalej: AZHRL), PSL-7, Referat polityczno-programowy prezesa NKW PSL S. Mikołajczyka wygłoszony na V Kongresie PSL, 19 I 1946 r., k. 96; ibidem, Tezy projektu rezolucji o przebudowie ustroju rolnego. Wystapienie W. Droździka na V Kongresie PSL, 21 I 1946 r., k. 201-202. Szerzej o wizji ustroju rolnego w programie PSL w latach 1945-1946 zob. m.in.: M. Nadolski, Kwestia chtopska $w$ polityce stronnictw robotniczych i ludowych w Polsce w latach 1941-1947, Warszawa 1990, s. 85-91. 
działaczy PPR, mieli sabotować i opóźniać reformę rolną oraz sprzyjać innym wywłaszczanym „obszarnikom” ${ }^{17}$.

Na Warmii i Mazurach spora część stanowisk administratorów i rządców również została powierzona ziemianom. Komisarz Powiatowego Urzędu Ziemskiego (PUZ) w Ostródzie, ziemianin Jerzy Binzer, podczas pierwszego zjazdu kierowników PUZ w Olsztynie w dniach 29-30 X 1945 r., na pytanie wiceministra rolnictwa i reform rolnych Stanisława Bieńka: „z jakiego elementu składają się zaangażowani administratorzy majątków?” - odpowiedział: „Dużo bardzo ziemian, poza tym b.[yli] administratorzy i rządcy" ${ }^{18}$. Co ciekawe, nie spotkało się to z krytyką kogokolwiek z uczestników wspomnianego zjazdu, a Binzer był stawiany innym komisarzom ziemskim za wzór, osoba, która sprawnie i skutecznie doprowadziła do uruchomienia majątków ziemskich na swoim terenie. Inni komisarze także chętnie na stanowiskach administratorów zatrudniali ziemian, jako odpowiednio przygotowanych fachowców. Zreszta niektórzy z nich również byli ziemianami. Z punktu widzenia tematyki tego artykułu warto wymienić dwóch: Jana Koziełł-Poklewskiego - komisarza PUZ w Moragu oraz wspomnianego Jerzego Binzera - komisarza PUZ w Ostródzie.

Bez wątpienia ziemianie i administratorzy przedwojennych dóbr ziemskich spełniali kryteria wykształcenia, fachowości i doświadczenia w pracy w wielkopowierzchniowych gospodarstwach. Angażowanie osób fachowo przygotowanych świadczyć może o tym, że urzędnikom ziemskim sympatyzującym z PSL zależało na sprawnym i efektywnym funkcjonowaniu gospodarstw państwowych, których ogromna część, przypomnijmy, miała być poddana parcelacji. Jednocześnie nakaz opuszczania własnych majątków ziemskich przejętych przez państwo w wyniku reformy rolnej zmuszał ich do poszukiwania nowych źródeł utrzymania i miejsc do osiedlenia się. Na ziemiach włączonych niemal do wszystkich majątków ziemskich szukano zarządców, w przeciwieństwie do tzw. ziem dawnych, na których w wyniku reformy rolnej „obszarnicze” folwarki w dużej części rozparcelowywano. Szansa na zdobycie posady na tzw. Ziemiach Odzyskanych była więc duża.

Wydaje się, że poza powyższym, merytorycznym czynnikiem, wpływ na powierzanie ziemianom stanowisk $\mathrm{w}$ aparacie rolnym i administracji poniemieckich majątków wywarła niezależność pracowników urzędów ziemskich od lokalnej administracji ogólnej. Zgodnie z dekretem z 15 VIII 1944 r. o organizacji wojewódzkich i powiatowych urzędów ziemskich stanowiły one sieć administracji niezespolonej, bezpośrednio podlegającej MRiRR ${ }^{19}$. W Okręgu

\footnotetext{
17 Zob. T. Osiński, „Klika obszarnicza”. Ziemianie w polityce personalnej Państwowych Nieruchomości Ziemskich (1946-1949), „Pamięć i Sprawiedliwość” 2012, nr 2, s. 232-236.

18 APO, WUZ, 618/18, Protokół z I Zjazdu kierowników PUZ Okręgu Mazurskiego w Olsztynie, 29-30 X 1945 r., k. 48v.

${ }_{19}$ Dz.U. 1944, nr 2, poz. 4.
} 
Mazurskim nie zależały więc od pełnomocnika rządu - Jakuba Prawina, związanego z PPR, lecz ministra rolnictwa i reform rolnych, tym samym nie mogły być kontrolowane przez komunistów w takim stopniu, w jakim tego ci ostatni oczekiwali ${ }^{20}$. MRiRR zdominowane było co prawda do końca czerwca 1945 r. przez „lubelskie” SL, choć w prace nad odbudową rolnictwa włączyli się także działacze ludowi popierajacy konspiracyjne SL „Roch”. W terenie, w urzędach ziemskich, najczęściej stanowiska powierzano ludowcom lub osobom sympatyzującym z szeroko rozumianym ruchem ludowym, bądź w inny sposób powiązanym z wsią. Po powrocie Mikołajczyka i przejęciu przez niego teki ministra rolnictwa i reform rolnych oraz funkcji wicepremiera wielu z nich przeszło z „lubelskiego” SL do ujawnionego SL „Roch”, później PSL, lub z nim sympatyzowało.

Można podejrzewać, że pracownicy urzędów ziemskich w Okręgu Mazurskim, początkowo odcięci od wpływów PPR, mieli dla swych poczynań personalnych ciche przyzwolenie, swoisty parasol ochronny ze strony Mikołajczyka, tym bardziej że wyludnienie na Warmii i Mazurach było ogromne, łatwo więc umotywowano by powierzanie ziemianom stanowisk administratorów lub rządców. Jednak brak wpływu PPR na politykę kadrową w pionie administracyjnym, zajmującym się zarządzaniem majątkami państwowymi, wyraźnie irytował lokalnych działaczy partyjnych, którzy z coraz większą nieufnościa przyglądali się, jak to określali, „zaśmieconej” kadrze urzędów ziemskich. Szef Wydziału Rolnego KW PPR Stanisław Lange w sprawozdaniu do KC donosił w styczniu $1946 \mathrm{r} .:$,w tych urzędach dobrała się jedna klika, która stara się, aby nikt im nie przeszkadzał"21.

Po utworzeniu PNZ, z perspektywy komunistów, wspomniany „problem” pogłębił się. Cechę charakterystyczną obsady personalnej władz centralnych i lokalnych nowo utworzonego przedsiębiorstwa stanowiła duża liczba ziemian. Znanym przedwojennym działaczem ziemiańskim był wspomniany dyrektor ZC PNZ Witold Maringe, który zdołał zgromadzić wokół siebie innych ziemian. Eugeniusz Kłoczowski, który w 1946 r. podjął pracę w ZC PNZ w Poznaniu, wspominał:

${ }^{20} \mathrm{~W}$ kwietniu 1945 r. doszło do konfliktu między pełnomocnikiem rządu RP na Okręg Mazurski Jakubem Prawinem i prezesem WUZ w Olsztynie Józefem Ptaszkiem. Prawin żądał włączenia WUZ do urzędu pełnomocnika, jako wydziału rolnego, na co Ptaszek się nie zgodził. Jego interwencja u ministra rolnictwa i reform rolnych Edwarda Bertolda odniosła sukces. Bertold wyraźnie zaznaczył, że wojewódzkie urzędy ziemskie bezpośrednio podlegały władzy MRiRR i nie mogły być podporządkowane lokalnej administracji ogólnej, co zresztą było zgodne z dekretem o utworzeniu urzędów ziemskich. Szerzej na temat tego sporu zob. R. Gross, Okręg Mazurski w świetle materiałów Wojewódzkiego Urzędu Ziemskiego w Olsztynie (marzec-maj 1945), „Echa Przeszłości” 2016, nr 17, s. 201-202.

${ }^{21}$ AAN, Komitet Centralny Polskiej Partii Robotniczej (dalej: KC PPR), 295/XII-61, Sprawozdanie Wydziału Rolnego KW PPR w Olsztynie, 19 I 1946 r., k. 47. 
Z krótkiej rozmowy z Maringe'em zrozumiałem, że miał on głęboką wiarę w słuszność zainicjowanej przez siebie - i zbliżoną doń grupę ludzi - akcji. To, że cały nasz dotychczasowy świat zawalił się całkowicie, że nie istnieje nawet iskierka nadziei, aby dawni ziemianie wrócić mogli do swoich majątków - było dla nas jasne. Zniszczony kraj potrzebuje chleba. Ziemie Odzyskane muszą być przez Polaków zagospodarowane, tego domaga się narodowy interes, abstrahując od kwestii, czy obecne rządy są nam sympatyczne, czy wrogie. Sensowne uruchomienie gospodarki rolnej na Śląsku, Pomorzu, Mazurach może być wykonane tylko przez ludzi, którzy są do tych trudnych zadań przygotowani fachowo. W Polsce jedyną grupa mogąca tego rodzaju zadanie podjąć są byli ziemianie ${ }^{22}$.

Komunistów niepokoił fakt, że powołane w lutym 1946 r. przedsiębiorstwo pozostawało poza ich kontrola. Upatrywali w urzędach ziemskich i PNZ instytucji, w których wpływy posiadało PSL, a schronienie znaleźli „obszarnicy”. W sprawozdaniu Wydziału Rolnego KW PPR w Olsztynie do KC z kwietnia 1946 r. czytamy: „Najbardziej zaśmieconym aparatem przez powyższe elementy, jest $u$ nas aparat gospodarczy, urzędy ziemskie. Jaskrawym przykładem jest właśnie akcja siewna na majątkach państwowych. Tam oni wykazują swoje mistrzostwo sabotażową robota" ${ }^{23}$. Z kolei w sprawozdaniu za okres od sierpnia 1945 do kwietnia 1946 r. Lange alarmował partyjną centralę:

jeżeli Partii naszej nie uda się w najbliższym czasie przeprowadzić czystki aparatu gospodarczego, szczególnie w urzędach ziemskich, w administracji majątków państwowych i to odgórnie, niebezpieczeństwo dalszego zaśmiecania tego aparatu jeszcze bardziej wzrośnie i wzmoże się jeszcze usilniej akcja sabotażowa ze strony tych elementów, szczególnie zaś w urzędach ziemskich i majątkach państwowych. Mówię z całą powaga, sytuacja dojrzała, by uderzyć w dzwon alarmowy ${ }^{24}$.

Nie ma wątpliwości, że zarzuty wysuwane przez działaczy PPR, dotyczące „nieodpowiednich” kadr w urzędach ziemskich i majątkach państwowych, wynikały z pobudek politycznych, a nie merytorycznych. Na marginesie przypomnijmy, że Lange sprawozdania te pisał w okresie szybkiej rozbudowy organizacyjnej PSL w Okręgu Mazurskim. Do końca marca 1946 r., obok struktur wojewódzkich, powstało już 14 zarządów powiatowych PSL ${ }^{25}$, co pośrednio wzmacniało także powiatowe struktury administracji rolnej.

Langemu wtórował naczelnik Wydziału IV WUBP w Olsztynie, który $\mathrm{w}$ okresie przejmowania majątków państwowych przez PNZ zanotował w raporcie do MBP: „Najgorzej przedstawia się do tej pory administracja majątków

22 E. Kłoczowski, op. cit., s. 20.

${ }_{23}$ AAN, KC PPR, 295/XII-61, Sprawozdanie Wydziału Rolnego KW PPR, 11 IV 1946 r., k. 68.

${ }^{24}$ APO, Komitet Wojewódzki Polskiej Partii Robotniczej (dalej: KW PPR), 1073/127, Sprawozdanie Wydziału Rolnego KW PPR za okres 1 VIII 1945 - 14 IV 1946 r., k. 81.

${ }^{25}$ Zob. B. Łukaszewicz, Polskie Stronnictwo Ludowe na Warmii i Mazurach $w$ latach 1945-1947, Olsztyn 1991, s. 39-44. 
państwowych w Okręgu Mazurskim, gdyż składa się z byłych dziedziców lub przedwojennych administratorów, którzy jednak nadal sa zwolennikami ustroju sprzed 1939 r." 26 Nowo powołane przedsiębiorstwo stało się więc obiektem zainteresowania UB. W kolejnym raporcie naczelnik Wydziału IV donosił: „Zarząd Nieruchomości Ziemskich nie jest jeszcze rozpoznany, ale już wyłowiliśmy kandydatów na werbunek, tak że w najbliższym czasie będziemy mieli konkretne dane" 27.

\title{
Infiltracja biura ZO PNZ w Olsztynie
}

Wstępne rozpoznanie składu personalnego kierownictwa ZO PNZ w Olsztynie przez WUBP dowodzić miało konieczności podjęcia jego bacznej obserwacji. W raporcie dekadowym kierownika Sekcji V w Wydziale IV WUBP z sierpnia 1946 r. czytamy:

\begin{abstract}
Dyrektorem tegoż urzędu [ZO PNZ w Olsztynie] jest ob. Nieniewski Adam, przedwojenny pułkownik Wojsk Polskich, lecz on lepiej by się nadawał na [inne] stanow. [isko] aniżeli dyrektora ZPNZ ponieważ o rolnictwie nie ma on żadnego pojęcia, a natomiast, jak podaje agentura, lubi się bawić wesoło i brać rozmaite podarki i prezenty. Do pomocy zaś ma swoich inspektorów [...]. Ci właśnie kieruja cała robota i dyrektorem, do tego stopnia, że jest obecnie w ich sercu tylko narzędziem wykonawczym. Jednym słowem [...] cały urząd tworzy jakby jedną rodzinę, zaś co do PPR i PPS - nie mają żadnego zaufania, woleliby PSL lub NSZ. Wydajność pracy jest bardzo znikoma i ograniczona ${ }^{28}$.
\end{abstract}

Ocena ta, niewątpliwie nieobiektywna, obciążona z góry założoną tezą o „szkodniczej” działalności „obszarników”, pozwala jednak wyciagnać wniosek, że stosunki panujące w ZO PNZ w Olsztynie z całą pewnością różniły się od atmosfery stworzonej w innych urzędach państwowych. Dodajmy, że o wyjątkowych stosunkach w poznańskim ZC PNZ wspominał Kłoczowski²9.

Funkcjonariusze UB dość szybko podjęli próbę pozyskania informacji i materiałów obciążających pracowników biura ZO PNZ w Olsztynie. W sierpniu

${ }^{26}$ Archiwum Instytutu Pamięci Narodowej Oddział w Białymstoku (dalej: AIPN Bi), Wojewódzki Urząd Bezpieczeństwa Publicznego w Olsztynie (dalej: WUBP), 084/67, Raport dekadowy od 20 do 31 III 1946 r. naczelnika Wydziału IV WUBP Rajmunda Podkowińskiego do MBP, k. 4.

${ }^{27}$ Ibidem, Raport dekadowy od 1 do 20 V 1946 r. naczelnika Wydziału IV WUBP por. W. Gruntowa do MBP, 21 V 1946 r., k. 7.

${ }^{28}$ Ibidem, Raport dekadowy p.o. kierownika Sekcji V Wydziału IV do MBP za okres 1-10 VIII 1946 r., 9 VIII 1946 r., k. 16.

${ }^{29}$ Kłoczowski, pracownik Wydziału Rolnego ZC PNZ, we wspomnieniach zapisał: „W Zarządzie Centralnym PNZ znalazłem świat zdrowy, odczarowany od kultu doktryny, od bojaźni i demagogii. Tu zebrali się ludzie, którzy chcieli robić coś twórczego i swobodni”. E. Kłoczowski, op. cit., s. 21. 
1946 r. oficerowie Wydziału IV WUBP założyli na terenie ZO PNZ w Olsztynie sprawę grupową agenturalnego rozpracowania o kryptonimie „Organizatorzy” na: naczelnika Wydziału Rolnego Władysława Łubczańskiego, inspektorów okręgowych Andrzeja Wilskiego i Antoniego Robotę oraz kierownika Oddziału Traktorów Lucjana Smulskiego. W uzasadnieniu podjęcia rozpracowania zanotowano: „w/w podejrzani sa o sianie propagandy antydemokratycznej i przynależność do nielegalnej organizacji podziemnej”30. W kwietniu $1947 \mathrm{r}$. w celu szybszego rozpracowania sprawy „Organizatorzy” zwerbowany został Lucjan Smulski, ps. Lucek, który do tej pory „przechodził w tej sprawie” ${ }^{31}$. Jednak Smulski dość szybko odmówił współpracy, co utrudniło funkcjonariuszom UB inwigilację pracowników olsztyńskiego biura $\mathrm{PNZ}$ w pierwszym okresie działalności ${ }^{32}$.

Fakt piastowania stanowisk kierowniczych w PNZ przez osoby o „niewłaściwym" pochodzeniu prowadził funkcjonariuszy UB do wniosku, że wszelkie trudności i nieprawidłowości w funkcjonowaniu przedsiębiorstwa są skutkiem ich złej woli:

Dyrekcja Okręgowa Zarządu Państwowych Nieruchomości Ziemskich stoi na bardzo niskim poziomie produktywnym z powodu, że wszystkie kierownicze stanowiska i innego personelu biurowego obsadzone są przez elementy rekrutujące się przeważnie z kliki obszarniczej i wszystkich wyższych oficerów Wojska Polskiego sprzed roku 1939, którzy są wrogo ustosunkowani do obecnego ustroju demokratycznego. Ludzie ci starają się wciagnąć elementy sympatyzujące im z innych instytucji, tworząc razem siedlisko reakcyjne, które jest nam bardzo trudno rozpracować ${ }^{33}$.

Początkowe trudności w pozyskaniu informatorów i zgromadzeniu materiałów obciążających osoby o „niewłaściwym” pochodzeniu lub życiorysie nie przeszkadzały funkcjonariuszom UB $\mathrm{w}$ ingerowaniu $\mathrm{w}$ funkcjonowanie pojedynczych gospodarstw i zespołów PNZ ${ }^{34}$. Dodajmy, że uwagi UB o obsadzeniu kierowniczych stanowisk w PNZ przez ziemian nie dotyczyły wyłącznie Warmii i Mazur. Podobne relacje spływały do Ministerstwa Bezpieczeństwa Publicznego (MBP) i KC także $\mathrm{z}$ innych województw ${ }^{35}$.

30 AIPN Bi, WUBP, 084/67, Raport miesięczny naczelnika Wydziału IV Stefana Raczyńskiego do MBP za okres 1-10 VIII 1946 r., 3 IX 1946 r., k. 20.

${ }^{31}$ Ibidem, Sprawozdanie miesięczne naczelnika Wydziału IV ppor. Zbigniewa Grajka do MBP za okres 1-30 IV 1947 r., 29 IV 1947 r., k. 71.

${ }^{32}$ We wrześniu $1947 \mathrm{r}$. Sekcja V WUBP zaniechała dalszego prowadzenia sprawy o krypt. „Organizatorzy”. Zob. ibidem, Sprawozdanie miesięczne naczelnika Wydziału IV ppor. Zbigniewa Grajka do MBP za okres 1 IX - 1 X 1947 r., 1 X 1947 r., k. 113.

${ }^{33}$ Ibidem, Raport dekadowy naczelnika Wydziału IV w/z chor. Stefana Raczyńskiego do MBP za okres 9-19 X 1946 r., 19 X 1946 r., k. 33.

${ }^{34}$ Zob. E. Kłoczowski, op. cit., s. 68-69.

${ }^{35}$ Zob. T. Osiński, op. cit., s. 245-249. 


\section{Zmiany po wyborach 1947 r. - upartyjnienie personelu}

Wyniki sfałszowanych wyborów sejmowych z 19 I 1947 r. musiały wywrzeć na ekipie olsztyńskiego ZO PNZ duże wrażenie. Upadła ostatnia nadzieja na odsunięcie od władzy komunistów. Zmianę postaw kadry w biurze tego przedsiębiorstwa dostrzegli funkcjonariusze olsztyńskiego WUBP: „Na terenie Państwowych Nieruchomości Ziemskich, które były ośrodkiem gnieżdżącej się kliki wywłaszczonych panów, sytuacja polityczna z dniem 19 stycznia [1947 r.] zdawałoby się zmieniła się zupełnie. Od chwili przeprowadzenia wyborów, wzmógł się napływ członków do partii politycznych, a przeważnie do PPS" ${ }^{36}$. Z kolejnych relacji UB dowiadujemy się, że do 18 II 1947 r. do PPS wstapiło łącznie 50 pracowników ZO PNZ w Olsztynie ${ }^{37}$. Pracownicy okręgu olsztyńskiego wybór PPS uznawali za „mniejsze zło”; w ich przekonaniu, mógł ich chronić przed kadrową czystką. PPS było partią Bloku Demokratycznego, a więc koalicjantem PPR. Takie postawy kierownictwa ZO PNZ w Olsztynie można więc traktować jako formę samoobrony. Dodajmy, że komórkę PPR udało się powołać w ZO PNZ w Olsztynie dopiero w ostatniej dekadzie marca 1947 r., czyli po roku od utworzenia biura ${ }^{38}$.

\section{Zmiana dyrektora}

Przejęcie kontroli nad olsztyńskimi strukturami PNZ przez komunistów nastapiło po nagłej śmierci dyrektora Adama Nieniewskiego 25 IV 1947 r. ${ }^{39}$ Olsztyńscy komuniści dostrzegli wówczas szansę na objęcie tego stanowiska przez członka PPR. Z materiałów WUBP w Olsztynie dowiadujemy się, że doszło w tym czasie do wspólnych działań KW PPR z olsztyńskimi strukturami UB, które doprowadzić miały do powierzenia stanowiska dyrektora

\footnotetext{
${ }^{36}$ AIPN Bi, WUBP, 084/67, Raport dekadowy naczelnika Wydziału IV chor. Stefana Raczyńskiego do MBP za okres 23 I - 8 II 1947 r., 11 II 1947 r., k. 44.

${ }^{37}$ Ibidem, Raport dekadowy naczelnika Wydziału IV chor. Stefana Raczyńskiego do MBP za okres 8 II - 18 II 1947 r., 19 II 1947 r., k. 49.

${ }^{38}$ Ibidem, Sprawozdanie miesięczne naczelnika Wydziału IV ppor. Zbigniewa Grajka do MBP za okres 1 - 31 III 1947 r., 31 III 1947 r., k. 64.

${ }^{39}$ Okoliczności śmierci Adama Nieniewskiego nie sa do końca jasne. Oficjalne dokumenty mówią o śmierci nagłej, będącej skutkiem ataku serca. Jednak z niektórych relacji wynika, że mogły się do niej przyczynić częste kontrole biura okręgu olsztyńskiego PNZ dokonywane przez UB. Inspektor z ZO PNZ w Koszalinie we wspomnieniach zapisał następujące informacje usłyszane w czasie kursu inspektorów, odbytego zimą 1948 r.: „Omawiamy zasłyszane nowiny, zwłaszcza natury polityczno-represyjnej, jakie miały ostatnio miejsce w wielu okręgach PNZ. [...] W Olsztynie dyrektor okręgu zmarł na serce po kolejnej kontroli UB”. T. Czaplicki, Szlacheckie ostatki. Dwudziestowieczna opowieść polskiego ziemianina, Warszawa 2000, s. 328.
} 
Zarządu Okręgowego (ZO) PNZ w Olsztynie „godnemu zaufania” członkowi PPR. W sprawozdaniu z kwietnia $1947 \mathrm{r}$. naczelnik Wydziału IV WUBP ppor. Zbigniew Grajek zanotował: „Sekcja V [Wydziału IV WUBP] w porozumieniu z KW PPR Wydz. Rolny wytypowała 2-ch kandydatów członków PPR-u, aby wykorzystać moment [śmierć Nieniewskiego] i obsadzić człowiekiem partyjnym stanowisko dyrektora ZPNZ. Wytypowani sa inż. [Jan] Koziełł-Poklewski isnp. rolny z ZPNZ i inż. [Maksymilian] Wawrykiewicz ref.[erent] planowania w ZPNZ" ${ }^{40}$. Nie znamy metod i środków, jakie zostały użyte przez WUBP i KW PPR. Wiemy natomiast, że działania te przyniosły zamierzony cel. Dyrektorem ZO PNZ w Olsztynie został Jan Koziełł-Poklewski ${ }^{41}$.

Wraz z przejęciem władzy przez nowego dyrektora funkcjonariusze WUBP donosili centrali warszawskiej o pierwszych „sukcesach” personalnych w olsztyńskim ZO PNZ:

Po objęciu stanowiska dyrektora przez członka PPR ob. inż. Koziełł Polewskiego ZPNZ zmienił oblicze polityczne. Wszyscy ci, którzy byli wrogo ustosunkowani do obecnej rzeczywistości zostają stopniowo usuwani z pracy, a na ich miejsce stawia się ludzi oddanych sprawie demokracji ludowej. Zwolnieni zostali przeważnie obszarnicy, którzy starali się sabotować trzechletni plan odbudowy kraju [...] i wielu innych administratorów i rządców, którzy byli pozostałością byłego Ministra Rolnictwa i Ref. Rol. pana Mikołajczyka ${ }^{42}$.

Jak wynika z relacji, Poklewski z wielką energią przystapił więc do „czystki” kadrowej w objętym urzędzie.

\section{Obserwacja i przygotowanie materiałów obciążających}

Paradoksalne w akcji „przejęcia” kierownictwa nad ZO PNZ w Olsztynie, podjętej przez KW PPR i WUBP, było to, że nowy dyrektor Jan Koziełł-Poklewski stał się co prawda członkiem PPR i fachowcem z doświadczeniem, ale jednocześnie był również ziemianinem, co w kolejnych miesiącach okazało

${ }^{40}$ AIPN Bi, WUBP, 084/67, Sprawozdanie miesięczne naczelnika Wydziału IV ppor. Zbigniewa Grajka do MBP za okres 1-30 IV 1947 r., 29 IV 1947 r., k. 72.

${ }^{41}$ Jan Koziełł-Poklewski był protegowanym naczelnika Wydziału Rolnego KW PPR w Olsztynie Stanisława Langego, który w piśmie z marca $1947 \mathrm{r}$. do wicedyrektora ZC PNZ w Poznaniu rekomendował go na stanowisko inspektora w ZO PNZ w Olsztynie następująco: „mamy dobrego fachowca, naszego towarzysza, który był na jednym z powiatów komisarzem ziemskim, jest inżynierem, tak że całkowicie odpowiada wszystkim wymogom na to stanowisko. Takie przesunięcie personalne mocno by nam wzmocniło pozycję w PNZ oraz zmieniło by stosunki na lepsze w dyrekcji”. AIPN Delegatura w Olsztynie (dalej: Ol), Sąd Administracyjny w Olsztynie (dalej: SA), 9/4, Akta w sprawie karnej przeciwko Poklewskiemu i innym (sygn. akt I K 12/49), Pismo kierownika Wydziału Rolnego Stanisława Langego do wicedyrektora ZC PNZ w Poznaniu Borysa Szmielewa, 17 III 1947 r., k. 79.

${ }^{42}$ AIPN Bi, WUBP, 084/67, Sprawozdanie miesięczne naczelnika Wydziału IV ppor. Zbigniewa Grajka do MBP za okres 30 VI - 31 VII 1947 r., 1 VIII 1947 r., k. 89. 
się nie do zaakceptowania przez władze komunistyczne ${ }^{43}$. Funkcjonariusze Wydziału IV WUBP już po kilku miesiącach urzędowania Poklewskiego zaczęli zbierać materiały, które w przyszłości miały pozwolić na ewentualne postawienie go w stan oskarżenia. Z zachowanych akt sprawy Poklewskiego wynika, że pierwsze doniesienie na niego 25 IX 1947 r. złożył funkcjonariuszom UB Antoni Kamiński, który był dozorca ZO PNZ w Giżycku. Rozpoznał Poklewskiego, gdy ten wizytował okręg giżycki PNZ. Znał on Poklewskiego jeszcze z czasów przedwojennych, gdy pracował w jednym z majątków zarządzanych przez Poklewskiego na Wileńszczyźnie. Z treści doniesienia wynika, że Poklewski brutalnie odnosił się do robotników rolnych i podwładnych. Poza tym świadek miał go widzieć w 1944 r. w towarzystwie niemieckich arystokratów z wpiętym w klapę marynarki hitlerowskim krzyżem ${ }^{44}$. Doniesienie to stało się punktem wyjścia wstępnego dochodzenia funkcjonariuszy Wydziału IV WUBP, zmierzającego do pozyskania informacji o przeszłości i obecnych działaniach Poklewskiego. Przesłuchania kolejnych świadków w zasadzie potwierdzały zarzuty o nie najlepszym obchodzeniu się z pracownikami zatrudnionymi w majątkach administrowanych przez Poklewskiego w czasie wojny i jego dość bliskich związkach z administracja niemiecka ${ }^{45}$.

Funkcjonariusze WUBP zbierajac materiały przeciwko Poklewskiemu, zdawali sobie sprawę, że pozyskane informacje o współpracy z niemiecka administracją rolną mogą wystarczyć do wymierzenia kary więzienia dla Poklewskiego i zdjęcia go ze stanowiska dyrektora ZO PNZ w Olsztynie. Jednak taka kara nie posiadała waloru propagandowego. Głównym celem działań podjętych przeciwko Poklewskiemu miało być wykazanie, że w nowych powojennych warunkach, w czasach Polski Ludowej, on i inni ziemianie nie zdołali się „resocjalizować” i są środowiskiem, które szkodziło i szkodzić będzie nowemu ustrojowi. Odpowiednio nagłośniona kara miała także odgrywać rolę odstraszająca. Stąd funkcjonariusze UB poprzez informatorów pozyskiwali

${ }^{43}$ Trudno sobie wyobrazić, że przywoływany wyżej kierownik Wydziału Rolnego KW PPR w Olsztynie Stanisław Lange nie wiedział o ziemiańskim pochodzeniu Poklewskiego, gdy rekomendował go w marcu 1947 r. na stanowisko inspektora w ZO PNZ w Olsztynie. Jednak stosunek lokalnego aparatu PPR do Poklewskiego zaczą zmieniać się w końcu 1947 i w 1948 r., a więc po otrzymaniu z WUBP pierwszych informacji o materiałach obciążających Poklewskiego za działalność w okresie wojny (o czym dalej), zaostrzeniu walki z faktycznymi i domniemanymi wrogami nowej władzy oraz wytyczeniu nowych celów PNZ przez władze centralne (przesunięcie akcentów w działalności PNZ: z przygotowywania gruntów pod parcelację na utrzymanie możliwie największej domeny w posiadaniu państwa i zajęciu się produkcją własna; zob. P. Dziurzyński, Osadnictwo rolne na Ziemiach Odzyskanych, Warszawa 1983, s. 128-129).

${ }^{44}$ AIPN Ol, SA, 9/3-1, Akta w sprawie przeciwko Poklewskiemu (sygn. akt I K 10/49), Protokół przesłuchania świadka Antoniego Kamińskiego przez plut. Henryka Górskiego referenta PUBP w Giżycku, 25 IV [właśc. IX] 1947 r., k. 6.

${ }^{45}$ Ibidem, Protokół przesłuchania świadka Wacława Okuniewskiego, 14 X 1947 r., k. 7-9; ibidem, Protokół przesłuchania świadka Zygmunta Minejko, 25 VI 1948 r., k. 10-13; ibidem, Protokół przesłuchania świadka Czesława Łaszkiewicza, 16 VII 1948 r., k. 17. 
informacje nie tylko o przeszłości Poklewskiego, lecz także jego działaniach po objęciu funkcji dyrektora ZO PNZ. W styczniu 1948 r. WUBP dysponował pięcioma informatorami w różnych wydziałach ZO PNZ w Olsztynie i dążył do pozyskania kolejnych. Wyraźnie zmieniła się także w tym czasie ocena Poklewskiego w raportach UB. Szef Wydziału IV WUBP ppor. Zbigniew Grajek w sprawozdaniu do MBP zanotował: „Niezadowolenie wśród pracowników [ZO PNZ] wprowadza sam dyrektor [Jan] Koziełł-Poklewski przez ordynarny sposób odzywania się", czym zrażać miał do siebie urzędników biura i powodować ich samowolne zwolnienia. Poza tym zabraniał ponoć organizowania zebrań członków PPR w jednostkach gospodarczych przedsiębiorstwa. Po raz pierwszy pojawiły się także informacje mogące stanowić punkt wyjścia postawienia mu w późniejszym czasie zarzutu niegospodarności. Według nich dyrektor miał zaniedbywać kontrolę gospodarki zespołów wchodzacych w skład ZO PNZ w Olsztynie, a także zbyt często przenosić administratorów między poszczególnymi zespołami PNZ, co prowadziło do zakłócania płynności ich pracy ${ }^{46}$.

W kolejnych miesiącach funkcjonariusze Wydziału IV WUBP, prowadzący wstępne dochodzenie, wzbogacali dossier mające obciążyć Poklewskiego. W sprawozdaniu do MBP z marca 1948 r. zanotowano: „na miesiąc kwiecień planuje się zawerbować agenturę w sekretariacie [ZO PNZ] pod dyr. Poklewskiego, jak i w Wydz. Organizacyjnym"47. W kwietniu 1948 r. zainteresowano się wzrastająca liczbą osób zwalnianych z biura ZO PNZ w Olsztynie. Według informatora „Stefana” w wyniku zwolnień i rezygnacji z pracy powstała konieczność zatrudniania urzędników w godzinach nadliczbowych, co pochłonęło w ciąu miesiąca 100 tys. zł. Środki te, jego zdaniem, mogły wystarczyć na zatrudnienie 10 dodatkowych pracowników ${ }^{48}$. Przypomnijmy, że jeszcze sześć miesięcy wcześniej skutki „czystki” kadrowej prowadzonej przez Poklewskiego zupełnie inaczej oceniali funkcjonariusze UB.

\section{Aresztowania i przygotowanie procesów}

Początkowo, na podstawie zeznań świadków, pracownicy WUBP gromadzili materiały mające postawić Poklewskiego w stan oskarżenia z art. 1 ust. 1 i art. 2 i 3 Dekretu Polskiego Komitetu Wyzwolenia Narodowego z dnia

\footnotetext{
${ }^{46}$ AIPN Bi, WUBP, 084/69, Sprawozdanie ppor. Zbigniewa Grajka szefa Wydziału IV WUBP w Olsztynie do Departamentu IV MBP za okres 30 XII 1947 r. - 28 I 1948 r., 28 I 1948 r., k. 8-9.

${ }^{47}$ Ibidem, Sprawozdanie Aleksandra Pniewskiego p.o. kierownika Sekcji V Wydziału IV WUBP w Olsztynie do Departamentu IV MBP za okres 29 II 1948 r. - 31 IIII 1948 r., 31 III 1948 r., k. 21.

${ }^{48}$ Ibidem, Sprawozdanie Z. Strześniewskiego p.o. kierownika Sekcji V Wydziału IV WUBP w Olsztynie do Departamentu IV MBP okres 31 III 1948 r. - 30 IV 1948 r., 29 IV 1948 r., k. 25 .
} 
31 VIII 1944 r. „o wymiarze kary dla faszystowsko-hitlerowskich zbrodniarzy winnych zabójstw i znęcania się nad ludnością cywilna i jeńcami oraz dla zdrajców Narodu Polskiego" ${ }^{49}$. Artykuły te mówiły o udziale w dokonywaniu zabójstw, działaniu na szkodę państwa polskiego, osób prawnych oraz cywilnych i wojskowych w interesie „władzy państwa niemieckiego”, a także o wymuszaniu świadczeń „pod groźbą wywołania prześladowań przez władze państwa niemieckiego". Te sprawy do kwietnia 1949 r. rozpatrywał Sąd Okręgowy w Olsztynie. Jednocześnie przygotowywano zarzuty z art. 3 pkt 2 Dekretu z dnia 13 VI 1946 r. o przestępstwach szczególnie niebezpiecznych w okresie odbudowy Państwa ${ }^{50}$, mówiącym o aktach sabotażu przez uniemożliwienie lub utrudnienie prawidłowego działania zakładów lub urządzeń służących obronie państwa polskiego lub sprzymierzonego. Czyny z tego artykułu podlegały karze śmierci, dożywotniego więzienia lub więzienia na czas nie krótszy niż 3 lata. Sprawy o przestępstwa przewidziane z tego artykułu prowadził Wojskowy Sąd Rejonowy w Olsztynie ${ }^{51}$.

Na podstawie materiałów zgromadzonych przez Wydział IV WUBP w Olsztynie szef Wojskowej Prokuratury Rejonowej mjr Jerzy Tramer ${ }^{52} 2$ VIII 1948 r., w oparciu o art. 102, 103 i 104 Kodeksu wojskowego postępowania karnego, podjął decyzję o zastosowaniu środka zapobiegawczego w postaci tymczasowego aresztowania i osadzeniu Poklewskiego w areszcie przy WUBP w Olsztynie ${ }^{53}$. Poklewskiego zatrzymano 9 VIII 1948 r., a dalsze prowadzenie sprawy, wraz z podejrzanym i zgromadzonym materiałem obciążającym, przekazano z Wydziału IV do Wydziału Śledczego WUBP ${ }^{54}$. Tymczasowy

${ }^{49}$ Dz.U. 1944, nr 4, poz. 16, tekst jedn. Dz.U. 1946, nr 69, poz. 377.

${ }^{50}$ Dz.U. 1946, nr 30, poz. 192.

${ }^{51}$ Zob. ibidem, art. 51.

52 Jerzy Tramer (1915-1980) - absolwent prawa UJK (1937), żołnierz Okręgu Lwów AK (1941-1944), od 1944 w WP: oficer śledczy Wojskowej Prokuratury 10 DP (1945), oficer śledczy Wojskowej Prokuratury 2 Armii WP (1945), prokurator Wojskowej Prokuratury 8 DP (1945-1946), wiceprokurator WPO nr II w Bydgoszczy (1946-1948), prokurator WPR w Olsztynie (1948-1950). Szerzej zob. K. Szwagrzyk, Prawnicy czasu bezprawia. Sędziowie $i$ prokuratorzy wojskowi $w$ Polsce 1944-1956, Kraków-Wrocław 2005, s. 451. Na temat obsady personalnej WPR w Olsztynie zob. też: B. Łukaszewicz, Wojskowy Sad Rejonowy $w$ Olsztynie 1946-1955. Szkice do monografii, Olsztyn 2000, s. 28-32.

${ }^{53}$ AIPN Ol, SA, 9/3-1, Postanowienie o tymczasowym aresztowaniu, 2 VIII 1948 r., k. 23.

${ }^{54}$ Zgodnie z art. 55 dekretu z 13 VI 1946 r. o przestępstwach szczególnie niebezpiecznych postępowanie przygotowawcze w sprawach o przestępstwa określone w tym dekrecie i podlegające właściwości sądów wojskowych prowadziły „organy bezpieczeństwa publicznego”, a nadzór nad postępowaniem sprawował prokurator wojskowy. Zob. Dz.U. 1946, nr 30, poz. 192. Szerzej o postępowaniu przygotowawczym jako nowej procedurze karnej w pierwszych latach powojennych, w której sędziów śledczych zastapili funkcjonariusze UB, zob. A. Lityński, Na drodze ku nowej procedurze karnej: o postepowaniu przygotowawczym w latach 1943-1950, w: Przestępstwa sędziów i prokuratorów w Polsce lat 1944-1956, red. W. Kulesza, A. Rzepliński, Warszawa 2001, s. 49-66; E. Romanowska, Karzqce ramię sprawiedliwości ludowej. Prokuratury wojskowe w Polsce w latach 1944-1955, Warszawa 2012, s. 307-343. 
areszt prokurator wojskowy przedłużał przez kolejnych sześć miesięcy, po czym, po wyczerpaniu przez prokuratora możliwości prawnych do dalszego przedłużania aresztu tymczasowego, Wojskowy Sąd Rejonowy w Olsztynie podczas posiedzenia niejawnego 4 II 1949 r. zdecydował o kolejnym przedłużeniu aresztu tymczasowego do 10 IV $1949 \mathrm{r.}^{55}$

W tym czasie szeroko zarzucona „sieć” przez WUBP w ZO PNZ w Olsztynie pozwolić miała na „wyłowienie” współpracowników Poklewskiego i zgromadzenie materiałów ich obciążajacych ${ }^{56}$. Kierunek śledztwa prowadzonego przez funkcjonariuszy UB pomogła wytyczyć generalna lustracja ZO PNZ, dokonana po aresztowaniu Poklewskiego przez Inspektorat Generalny PNZ $\mathrm{w}$ dniach od 12 IX do 16 X 1948 r. $^{57}$ Początkowo lustracja odbywała się pod kierownictwem inspektora ZC PNZ Zbigniewa Roboty, ale ten nie budził zaufania funkcjonariuszy UB. Szef WUBP w Olsztynie w sprawozdaniu do MBP przypomniał, że Robota w latach 1946-1947 był inspektorem w Okręgu PNZ Olsztyn i „przechodził w sprawie agenturalnego rozpracowania. W związku z tym Wydział IV w porozumieniu z KC PPR i [głównym] inspektorem [ZC PNZ] Hanyszem [Stanisławem Hanyżem] czł. PPR usunął insp. Robotę, a na przewodniczącego komisji powołał insp. [Zdzisława] Kowalika czł. PPR”58. Zmiana ta miała zagwarantować uzyskanie „właściwych” wyników lustracji, czyli obciążajacych kierownictwo okręgu olsztyńskiego. Po ponad miesięcznej, szczegółowej kontroli szef Sekcji V Wydziału IV WUBP meldował centrali: „Przez cały czas inspekcji Wydz.[iał] IV był w porozumieniu z inspektorem Kowalikiem, który część protokołów poinspekcyjnych pozostawił celem wyciagnięcia konsekwencji [...], a część ma dostarczyć po ukończeniu ich w Centrali" ${ }^{59}$. Najpoważniejsze zarzuty postawione dyrekcji ZO PNZ w Olsztynie we wspomnianym sprawozdaniu pokontrolnym dotyczyły niewłaściwej polityki personalnej oraz nieodpowiednich metod planowania wielkości produkcji rolnej ${ }^{60}$.

Kierując się rezultatami powyższej kontroli, głównym zadaniem oficerów śledczych stało się wykazanie $\mathrm{w}$ toku śledztwa niegospodarności w przedsiębiorstwie, będących wynikiem zaniedbań osób zajmujących kierownicze stanowiska i błędnej polityki personalnej. Dlatego obserwacja informatorów

${ }_{55}$ AIPN Ol, SA, 9/3-1, Wyciagg z protokołu posiedzenia niejawnego WSR z 4 II 1949 r., k. 85.

${ }^{56}$ AIPN Bi, WUBP, 084/69, Sprawozdanie Zenona Strześniewskiego p.o. kierownika Sekcji V Wydziału IV WUBP w Olsztynie do Departamentu IV MBP za okres 1-31 VIII 1948 r., 1 IX 1948 r., k. 62.

${ }^{57}$ AAN, KC PPR, 295/XII-249, Sprawozdanie z generalnej lustracji ZO PNZ w Olsztynie w dniach 12 IX - 16 X 1948 r., 23 XI 1948 r., k. 12-73.

58 AIPN Bi, WUBP, 084/86, Sprawozdanie miesięczne ppłk. H. Palki szefa WUBP do MBP za okres 1-30 IX 1948 r., 2 X 1948 r., k. 137.

59 AIPN Bi, WUBP, 084/69, Sprawozdanie miesięczne Zenona Strześniewskiego kierownika Sekcji V Wydziału IV WUBP do MBP za okres 1-30 X 1948 r., k. 70.

${ }^{60}$ AAN, KC PPR, 295/XII-249, Sprawozdanie z generalnej lustracji ZO PNZ w Olsztynie w dniach 12 IX - 16 X 1948 r., 23 XI 1948 r., k. 12-73. 
WUBP zogniskowała się na szefach dwóch wydziałów w ZO PNZ: Rolnego i Personalnego. Na czele pierwszego stał wymieniany już ziemianin Jerzy Binzer, który w latach 1945-1947 był komisarzem ziemskim w PUZ w Ostródzie. Wydziałem Personalnym w ZO PNZ w Olsztynie kierował Stefan Kossakowski, którego inspektor Inspektoratu Głównego ZC PNZ Zdzisław Kowalik tuż przed aresztowaniem scharakteryzował następująco: „według zaczerpniętych informacji jest to przedwojenny pułkownik, piłsudczyk, dwójkarz, a więc wróg numer jeden ustroju Polski Ludowej, Polski Socjalnej, jest człowiekiem, który zapędzał ludzi o lewicowym nastawieniu do więzień i Berezy Kartuskiej. Dziś taki człowiek stoi na powyższym stanowisku, jakim jest Wydział Personalny" ${ }^{61}$. Obaj więc byli odpowiedni z punktu widzenia potrzeb uzyskania propagandowego efektu przygotowywanego procesu pokazowego. Oficerowie śledczy WUBP pierwotnie gromadzili przeciwko nim materiały mające pozwolić postawić im zarzuty z art. 3 pkt 2 dekretu z 13 VI 1946 r., a więc z jednego z artykułów, którego złamanie przypisywali również Poklewskiemu. Stąd 10 XII 1948 r. wojskowy prokurator rejonowy w Olsztynie wydał postanowienie o tymczasowym aresztowaniu Binzera i Kossakowskiego, które później przedłużano ${ }^{62}$. Jak zapisał szef WUBP w Olsztynie, obaj „zostali włączeni do sprawy przeciwko Poklewskiemu" ${ }^{\text {. }}$.

29 III 1949 r. chor. Eugeniusz Oberek, oficer śledczy WUBP w Olsztynie, wydał dość interesujące postanowienie o zmianie kwalifikacji czynu zarzucanego Poklewskiemu, Binzerowi i Kossakowskiemu ${ }^{64}$. Postanowienie umarzało postępowanie przeciwko nim z art. 3 pkt 2 dekretu z 13 VI 1946 r. (które leżało we właściwościach Wojskowego Sądu Rejonowego) i jednocześnie zarzucało złamanie art. 39 pkt 1 i 2 tego samego dekretu, dotyczacych przestępstwa przeciwko interesom gospodarczym państwa, obniżania wytwórczości i zmniejszania wydajności pracy oraz marnotrawstwa w zakładach państwowych. Przestępstwo określone $\mathrm{w}$ tym artykule podlegało niesprecyzowanej czasowo karze więzienia. Zmiana kwalifikacji zarzucanego czynu niosła za soba istotne konsekwencje w dalszym postępowaniu karnym. Z jednej strony „wyjęto" sprawę spod właściwości Wojskowego Sądu Rejonowego, z drugiej, na krótko, znalazła się we właściwości Sądu Okręgowego w Olsztynie, gdyż

${ }^{61}$ Ibidem, Sprawozdanie z przeprowadzonej kontroli Wydziału Personalnego ZO PNZ w Olsztynie przez insp. ZC Zdzisława Kowalika, 23 XI 1948 r., k. 74.

${ }^{62}$ AIPN Ol, SA, 9/3-1, Postanowienie prokuratora Sądu Okręgowego w Olsztynie o tymczasowym aresztowaniu Jerzego Binzera, 4 IV 1949 r., k. 91-92; ibidem, Postanowienie prokuratora Sądu Okręgowego w Olsztynie o tymczasowym aresztowaniu Stefana Kossakowskiego, 4 IV 1949 r., k. 93-94; ibidem, Wniosek wiceprokuratora Sądu Okręgowego w Olsztynie do Sądu Okręgowego o przedłużenie tymczasowego aresztu, [b.d.], k. 96-97.

${ }^{63}$ AIPN Bi, WUBP, 084/86, Sprawozdanie miesięczne ppłk H. Palki szefa WUBP do MBP za okres 1 XII 1948 - 1 I 1949 r., 3 I 1949 r., k. 173.

${ }^{64}$ AIPN Ol, SA, 9/3-1, Postanowienie o częściowym umorzeniu postępowania i o przekazaniu sprawy według właściwości, 29 III 1949 r., k. 86-87. Postanowienie to sygnował nieczytelnym podpisem naczelnik Wydziału Śledczego WUBP w Olsztynie kpt. Antoni Trybus. 
zgodnie z ustawa z 27 IV 1949 r., zmieniająca przepisy postępowania karnego, właściwe do rozpatrzenia tych spraw stały się sądy apelacyjne (art. 22 $\S 1$ pkt $2 \mathrm{kpk})^{65}$. Decyzja ta stwarzała także możliwość zastosowania trybu doraźnego w postępowaniu sądowym, a to z kolei oznaczać mogło przyspieszony tryb sądzenia przed Sądem Apelacyjnym w Olsztynie ${ }^{66}$, wyższe kary i brak możliwości zaskarżenia wyroków ${ }^{67}$.

Powyższe postanowienie oficera śledczego, zmieniające kwalifikację czynów zarzucanych podejrzanym, z pewnością nie było wynikiem jego samodzielnej decyzji. Faktycznych autorów postanowienia prawdopodobnie należy szukać w Wojskowej Prokuraturze Rejonowej, która sprawowała formalny nadzór nad śledztwem oraz KW PZPR ${ }^{68}$. Być może wówczas na szczytach lokalnych struktur partyjnych zapadała decyzja o zorganizowaniu podejrzanym procesu pokazowego w trybie doraźnym. Wspomniane postanowienie z 29 III $1949 \mathrm{r}$. oficera śledczego WUBP w Olsztynie trafiło do wojskowego prokuratora rejonowego mjr. Jerzego Tramera, który z kolei sprawę wraz z aktami przekazał prokuratorowi Sądu Okręgowego w Olsztynie, a ten 6 IV 1949 r. wszczął śledztwo przeciw Poklewskiemu, Binzerowi i Kossakowskiemu ${ }^{69}$. Jednocześnie utrzymano wobec Poklewskiego wspomniane zarzuty o przestępstwo z art. 1 ust. 1 i art. 2 i 3 dekretu z 31 VIII 1944 r. Właściwy do ich rozpatrzenia, zgodnie ze zmienionym 27 IV 1949 r. kpk, był także Sąd Apelacyjny (art. $22 \S 1$ pkt 3 kpk).

${ }^{65}$ Kodeks postępowania karnego (tekst jedn. z 18 V 1949 r.), Dz.U. 1949, nr 33, poz. 243.

${ }^{66}$ Postępowanie doraźne wprowadzał dekret z 16 XI 1945 r. (Dz.U. 1945, nr 53, poz. 301), dwukrotnie znowelizowany: 13 VI 1946 r. (Dz.U. 1946, poz. 193) i 27 IV 1949 r. (Dz.U. 1949, nr 32, poz. 239). Od połowy 1949 r. zgodnie z drugą nowelizacją rozpoznawanie spraw w trybie doraźnym podlegało właściwości sądów apelacyjnych (zob. dekret o postępowaniu doraźnym z 15 XI 1945 r. z późn. zm., tekst. jedn. z 18 V 1949 r., Dz.U. 1949, nr 33, poz. 244, art. 4). Co prawda dekret z 25 VI 1946 r. o przystosowaniu przepisów o postępowaniu doraźnym do postępowania przed sądami wojskowymi pozwalał na zastosowanie takiego trybu w postępowaniu przed Wojskowym Sądem Rejonowym, ale nie wobec oskarżonych z art. 3 pkt 2 dekretu z 13 VI 1946 r. o przestępstwach szczególnie niebezpiecznych (Dz.U. 1946, nr 30, poz. 192). O złamanie tego właśnie przepisu początkowo toczyło się postępowanie przeciw Poklewskiemu, Binzerowi i Kossakowskiemu.

${ }^{67}$ Postępowanie w trybie doraźnym pozwalało wymierzyć wyższy wymiar kary: karę śmierci, karę dożywotniego więzienia, karę więzienia nie krótszą niż przewidziana w ustawie za dane przestępstwo. Sąd po odbyciu narady zobowiąany był do natychmiastowego ogłoszenia wyroku. Wyroki i postanowienia sądu nie podlegały zaskarżeniu (zob. ibidem, art. 2, art. 13 ust. 1 i 4). O rozszerzaniu zakresu przepisów karnych podlegających rozpoznaniu w trybie doraźnym zob. Z.A. Ziemba, Prawo przeciwko spoteczeństwu. Polskie prawo karne w latach 1944-1956, Warszawa 1997, s. 332 i n.

${ }^{68} \mathrm{O}$ pełnej dyspozycyjności i słabym wykształceniu funkcjonariuszy pionu śledczego w urzędach bezpieczeństwa szerzej zob. E. Romanowska, op. cit., s. 321; A. Dudek, A. Paczkowski, Kadry organów bezpieczeństwa, w: Czekiści. Organy bezpieczeństwa w europejskich krajach bloku wschodniego 1944-1989, red. K. Persak, Ł. Kamiński, Warszawa 2010, s. 417-424.

${ }^{69}$ AIPN Ol, SA, 9/3-1, Pismo prokuratora Wojskowej Prokuratury Rejonowej do prokuratora Sądu Okręgowego w Olsztynie, 1 IV 1949 r., k. 88; ibidem, Postanowienia o wszczęciu postępowania przeciwko J. Koziełł-Poklewskiemu, J. Binzerowi i S. Kossakowskiemu, k. 89-94. 
Z ramienia Prokuratury Sądu Okręgowego w Olsztynie sprawę prowadził wiceprokurator V Rejonu Leon Wiśniewski. Do lipca $1949 \mathrm{r}$. wszystkie zarzuty przeciw Poklewskiemu, Binzerowi i Kossakowskiemu umieszczono w jednym postępowaniu. Jednak w lipcu 1949 r. ponownie zmieniono im kwalifikację zarzucanych czynów z art. 39 pkt 1 i 2 dekretu z 13 VI 1946 r. (przewidującego nieokreśloną czasowo karę więzienia) na zarzuty z art. $286 \S 1 \mathrm{kk}$, który odnosił się m.in. do przestępstw urzędniczych na szkodę interesu publicznego (przewidującego karę więzienia do lat 5). Zarzuty z tego artykułu podlegały doraźnemu trybowi postępowania sądowego ${ }^{70}$, więc kara przewidziana w Kodeksie karnym mogła być wyższa. Natomiast zarzuty stawiane Poklewskiemu z art. 1 pkt 1 i art. 2 dekretu z 31 VIII 1944 r. „o wymiarze kary dla faszystowsko-hitlerowskich zbrodniarzy wojennych" podlegały zwykłemu trybowi postępowania sądowego. Okoliczność ta wymagała przeprowadzenia dwóch odrębnych postępowań sądowych, choć obu toczonych przed Sądem Apelacyjnym w Olsztynie ${ }^{71}$.

\section{Procesy i wyroki}

Jako pierwsza odbyła się rozprawa w trybie zwykłym przeciw Janowi Koziełł-Poklewskiemu z art. 1 pkt 2 i art. 2 dekretu z 31 VIII 1944 r. „o wymiarze kary dla faszystowsko-hitlerowskich zbrodniarzy wojennych”. 27 VII $1949 \mathrm{r}$. prokurator Sądu Okręgowego zamknął śledztwo przeciw Poklewskiemu, uznawszy, że „dostarczyło ono podstawy do rozprawy głównej”72, i wystawił akt oskarżenia Poklewskiego o to, „że wskazał niemieckim władzom bezpieczeństwa dwóch Polaków należących do podziemnej organizacji bojowej i prześladowanych ze względów politycznych”, a także o to, że „idąc na rękę władzy państwa niemieckiego działał na szkodę ludności polskiej cywilnej”73. Postanowienie wraz z aktem oskarżenia, zgodnie z właściwościa, przesłano do prokuratora Sądu Apelacyjnego w Olsztynie, a ten, na zasadzie art. 22 $\S 1$ kpk, 16 VIII 1949 r. wniósł akt oskarżenia do Sądu Apelacyjnego w Olsztynie $^{74}$. Rozprawę wyznaczono na 16 IX 1949 r., przydzielając Poklewskiemu obrońcę z urzędu - Władysława Nitkę.

${ }^{70}$ Zob. art. 1 ust. (1) lit. „d” dekretu o postępowaniu doraźnym z 15 XI 1945 r., z późn. zm., tekst. jedn. z 18 V 1949 r., Dz.U. 1949, nr 33, poz. 244.

71 Wiśniewski wydał także postanowienie o założeniu dla obu spraw odrębnych akt. Zob. AIPN Ol, SA, 9/3-1, Postanowienie wiceprokuratora Rejonu V Prokuratury Sądu Okręgowego w Olsztynie o rozdzieleniu akt, 19 VII 1949 r., k. 5.

72 Ibidem, Postanowienie wiceprokuratora Rejonu V Prokuratury Sądu Okręgowego w Olsztynie z 27 VII 1949 r., k. 229.

${ }^{73}$ Ibidem, Akt oskarżenia przeciwko J. Koziełł-Poklewskiemu, 27 VII 1949 r., k. 232-238.

${ }^{74}$ Ibidem. 
Rozprawie przewodniczył sędzia T. Gdowski delegowany z Sądu Apelacyjnego w Poznaniu. Zarzutom dotyczącym współpracy z Niemcami i spowodowania wywiezienia dwóch rodzin na roboty przymusowe do Niemiec Poklewski zaprzeczył. Co więcej, stwierdził, że wielu robotnikom zatrudnionym w majątkach pomagał. Pomocy miał także udzielać osobom niepracującym, spoza majątków, wystawiając zaświadczenia o zatrudnieniu, które chronić ich miały przed wywiezieniem do Niemiec. Podczas rozprawy przesłuchano 10 świadków. Dodajmy, że kilkakrotnie sędzia musiał podejmować decyzję o odczytaniu świadkom ich wcześniejszych zeznań. Ich relacje, rozmijające się z zeznaniami złożonymi podczas śledztwa, dowodza, że nie były one samodzielne, lecz prawdopodobnie w części inspirowane przez śledczych. Przykładowo świadek Jan Waśniewski na zarzut składania podczas rozprawy odmiennych zeznań odpowiedział, że jego zeznania nie były jego spostrzeżeniami, lecz „usłyszał to wszystko od innych ludzi”"

O stosunku składu sędziowskiego do oskarżonego i jednocześnie próbie usprawiedliwienia wyroku skazującego świadczą zmiany dokonane w protokole rozprawy. W przypadku tych fragmentów zeznań świadków, które mogłyby rzucić cień wątpliwości na winę Poklewskiego, dokonywano korekt. Jak się wydaje, najistotniejsza dotyczyła zeznania złożonego przez ówczesnego prokuratora Naczelnej Prokuratury Wojskowej Karola Johana, występującego w roli świadka, który podczas wojny był podwładnym Poklewskiego, pracując na stanowisku kancelisty w majątku w Nowosiółkach na Wileńszczyźnie. Po fragmencie odnoszacym się do kluczowej kwestii - doprowadzenia przez Poklewskiego do wywiezienia dwóch rodzin na roboty przymusowe - zakończonym stwierdzeniem, że „oskarżony w niektórych wypadkach ratował ludzi przed wywiezieniem na roboty do Niemiec. Kazał ludziom wystawiać zaświadczenia, mimo tego, że ci nie pracowali”, innym kolorem atramentu zapisano zdanie, które osłabiało moc poprzednich: „Czynił to jednak w nielicznych wypadkach i dla swoich znajomych"76. Trudno jednoznacznie stwierdzić, czy dodano je za wiedzą i zgoda świadka. Dużo wskazuje na to, że zostało ono dopisane już po rozprawie. Protokół rozprawy kończą trzy lakoniczne zdania: „Oskarżyciel publiczny [wiceprokurator Sądu Okręgowego Leon Wiśniewski - R.G.] wnosi o wymierzenie Janowi Poklewskiemu-Koziełło najwyższego wymiaru kary. Obrońca wnosi o uniewinnienie oskarżonego. Oskarżony w ostatnim głosie prosi o uniewinnienie" 77 . Z protokołu nie wynika więc, czy w ostatnim zdaniu Poklewski odniósł się do zeznań obciążajacych go. Prośba o uniewinnienie świadczyć może o tym, że nie przyznał się do stawianych mu zarzutów. Sąd w ogłoszonym wyroku uznał Poklewskiego za winnego, który dopuścił się czynu opisanego w punkcie 2 oskarżenia, a więc tego, że współpracując

\footnotetext{
${ }^{75}$ AIPN, Ol, SA, 9/3-2, Protokół rozprawy głównej, 16 IX 1949 r., k. 383.

${ }^{76}$ Ibidem, k. 371.

${ }^{77}$ Ibidem, k. 388.
} 
z administracją niemiecka, działał na szkodę polskiej ludności cywilnej, i skazał go, na zasadzie art. 2 dekretu z 31 VIII 1944 r., na kare 15 lat więzienia, zaliczając na poczet kary areszt tymczasowy od 9 VIII $1948 \mathrm{r.}^{78}$

20 IX 1945 r. adwokat Władysław Nitka wniósł do Wydziału Karnego Sądu Apelacyjnego w Olsztynie wniosek o rewizję wyroku. Zają się nią 2 XII 1949 r. Sąd Najwyższy. Rozprawie przewodniczył sędzia Zygmunt Kapitaniak. Rewizję Sąd Najwyższy oddalił, tym samym 2 XII 1949 r. wyrok się uprawomocnił ${ }^{79}$.

\section{Drugi proces}

Poza zarzutami z czasów wojny, jak już wspomniano, gromadzono na Poklewskiego i jego współpracowników zarzuty związane z niegospodarnością w ZO PNZ w Olsztynie. Wydaje się, że działania oficerów śledczych WUBP, a później Prokuratury Sądu Okręgowego, a także Sądu Apelacyjnego, głównie na tych zarzutach się skupiły, natomiast zarzuty, akt oskarżenia i rozprawę z 16 IX 1949 r. traktowano jako sprawę „odpryskowa”. W celu uzupełnienia materiałów obciążajacych Sąd Apelacyjny zażądał od ZO PGR w Olsztynie m.in. akt personalnych pracowników PNZ w okręgu olsztyńskim, zwolnionych w okresie kierowania przedsiębiorstwem przez Poklewskiego (czerwiec 1947 - sierpień 1948), a także akt dotyczących nadużyć gospodarczych w okręgu olsztyńskim PNZ. Starano się wykazać, że w okresie tym ruch kadrowy był zbyt duży i w dodatku dotyczyć miał zwalniania i nieprzyjmowania do pracy członków $\mathrm{PPR}^{80}$, a także dążono do wykazania zaniedbań kierownictwa ZO PNZ ${ }^{81}$.

Właściwa rozprawa odbyła się przed Sądem Apelacyjnym w Olsztynie w trybie doraźnym w dniach od 26 IX do 6 X 1949 r. Przewodniczył jej sędzia Z. Tęgowski, a ławnikami byli Michał Sokołowski ${ }^{82}$ i Marian Poloński ${ }^{83}$. Z akt

${ }^{78}$ Ibidem, Sentencja wyroku, 16 IX 1949 r., k. 389-390.

${ }^{79}$ Ibidem, Wyrok Sądu Najwyższego, 2 XII 1949 r., k. 431.

${ }^{80}$ Według informacji UB lustracja Wydziału Personalnego ZO PNZ w Olsztynie, przeprowadzona jesienią 1948 r., wykazała, że 90\% podań o pracę członków PPR zostało rozpatrzonych negatywnie. Zob. AIPN Bi, WUBP, 084/69, Sprawozdanie miesięczne naczelnika Wydziału IV WUBP do MBP za okres 1 XI - 1 XII 1948 r., k. 81.

${ }^{81}$ AIPN Ol, SA, 9/4, Pismo dyrektora ZO PGR w Olsztynie do Sądu Apelacyjnego w Olsztynie, 24 IX 1949 r., k. 127.

${ }^{82}$ Michał Sokołowski - od IV 1945 do IV 1946 r. I sekretarz KW PPR w Olsztynie, od VII 1945 r. wiceprezes, od II 1946 r. prezes Zarządu Wojewódzkiego Związku Samopomocy Chłopskiej w Olsztynie. Od V 1946 r. szef wojewódzkich struktur Towarzystwa Przyjaźni Polsko-Radzieckiej.

${ }^{83}$ Marian Poloński - do 1948 r. w PPS, od IV do XII 1945 naczelnik Wojewódzkiego Urzędu Informacji i Propagandy, później w Ministerstwie Informacji i Propagandy, delegat na Kongres Zjednoczeniowy w XII 1948 r., od 1948 członek Egzekutywy KW PZPR w Olsztynie, w 1949 r. kierownik Wydziału Socjalnego KW PZPR. 
sprawy i treści wyroku wynika, że oskarżonym zarzucono złamanie art. 286 $\S 1$, a Poklewskiemu - dodatkowo art. $287 \S 1 \mathrm{kk}$. Tego ostatniego oskarżono o działanie na szkodę interesu publicznego, stosowanie „szkodliwej polityki personalnej”, a szczególnie o liczne zwolnienia i zbędne przenoszenie pracowników, „nietaktowne i aspołeczne traktowanie” podwładnych, brak dbałości o zagospodarowanie majątków i brak nadzoru nad podległym personelem, doprowadzenie do chaosu i dezorganizacji pracy w biurze i majątkach ZO PNZ w Olsztynie. Działania te, według biegłych Bernarda Berdychowskiego i Antoniego Erdmana, miały spowodować straty sięgające ponad $75 \mathrm{mln} \mathrm{z}^{84}$.

Stefana Kossakowskiego, jako byłego naczelnika Wydziału Personalnego, oskarżono o niewłaściwa politykę personalną, działanie na szkodę interesu publicznego „przez to, że dokonywał licznych i zbędnych zwolnień oraz przenoszeń pracowników biurowych, administratorów i rządców, częstokroć w okresach niepożądanych dla przeprowadzenia zmian w gospodarce rolnej”, czym przyczynić się miał do powstania wyżej wymienionych strat materialnych. Natomiast Jerzemu Binzerowi zarzucono to, że jako naczelnik Wydziału Rolnego ZO PNZ działał na szkodę interesu publicznego „przez to, że nie kontrolował należycie pracy podległego personelu, a szczególnie rządców i administratorów w majątkach oraz referenta hodowlanego", czym także przyczynił się do wskazanych wyżej strat ${ }^{85}$.

Niestety nie zachował się protokół rozprawy. Nie wiemy więc, czy i ewentualnie w jaki sposób oskarżeni odpowiadali na zarzuty postawione przez prokuratora, jak odnieśli się do opinii biegłych. Sąd Apelacyjny uznał oskarżonych za winnych zarzucanych im czynów. Jana Koziełł-Poklewskiego na zasadzie art. $286 \S 1 \mathrm{i}$ art. $287 \S 1 \mathrm{kk}$ przy zastosowaniu art. 2 dekretu z 16 XI 1945 r. o postępowaniu doraźnym i art. 33 § 2 kk skazano na karę śmierci z pozbawieniem praw publicznych i obywatelskich praw honorowych na zawsze oraz przepadek mienia w całości na rzecz skarbu państwa. Stefana Kossakowskiego na zasadzie art. $286 \S 1$ kk przy zastosowaniu art. 2 dekretu z 16 XI 1945 r. o postępowaniu doraźnym skazano na 15 lat więzienia, a na mocy art. $47 \S 2 \mathrm{kk}$ i art. $52 \S 1 \mathrm{i} 3 \mathrm{kk}$ orzeczono utratę praw publicznych i obywatelskich praw honorowych na okres 5 lat. Jerzego Binzera uznano winnym zarzucanych mu czynów, jednak na mocy art. 1 ust. 6 dekretu z 16 XI 1945 r. o postępowaniu doraźnym stwierdzono, że czyn ten nie stanowi przestępstwa podlegającego postępowaniu doraźnemu, stąd wymierzona kara (na zasadzie art. $286 \S 1 \mathrm{kk}$ ) 3 lat więzienia, w porównaniu z karami Poklewskiego i Kossakowskiego, była dość niska ${ }^{86}$.

\footnotetext{
${ }^{84}$ AIPN Ol, SA, 9/4, Wyrok Sądu Apelacyjnego w Olsztynie w rozprawie przeciw J. Koziełł-Poklewskiemu, S. Kossakowskiemu i J. Binzerowi, 6 X 1949 r., k. 214.

${ }^{85}$ AIPN Ol, SA, 9/3-2, Sentencja wyroku Sądu Apelacyjnego w Olsztynie z dnia 6 X 1949 r., sygn. akt I K.12/49, k. 442-443.

${ }^{86}$ Ibidem, k. 443-444.
} 
Tak surowe kary orzeczone kierownictwu ZO PNZ w Olsztynie, szczególnie Poklewskiemu i Kossakowskiemu, odbiły się szerokim echem w środkach masowego przekazu ${ }^{87}$. Wydaje się, że propagandowy cel procesu i wyroków został osiagnięty. Przekaz kierowany do społeczeństwa wskazywać miał na umyślne działanie na szkodę interesu publicznego i sabotaż gospodarczy ${ }^{88}$.

\section{Rewizja wyroku i ułaskawienia}

Tuż po rozprawie skazani kolejno zwracali się z wnioskami o rewizję wyroku bądź prośbami o ułaskawienie. Co prawda postępowanie doraźne było jednoinstancyjne, jednak wobec uznania przez Sąd Apelacyjny w Olsztynie w wyroku z 6 X 1949 r., że czyn Jerzego Binzera nie stanowi przestępstwa podlegającego postępowaniu doraźnemu, Binzer wystapił 12 X 1949 r. z wnioskiem o rewizję wyroku, uważając karę 3 lat więzienia za zbyt surowa ${ }^{89}$. Sprawa weszła na wokandę Sądu Najwyższego, który 14 II 1950 r. w rozprawie rewizyjnej uchylił wyrok z 6 X 1949 r. w części dotyczącej Binzera i uniewinnił go ${ }^{90}$.

Po raz pierwszy z prośbą do Bolesława Bieruta o ułaskawienie męża zwróciła się Kazimiera Kossakowska 1 II 1950 r. Jednak opiniujący prośbę Sąd Apelacyjny w Olsztynie pozostawił ja „bez dalszego biegu” ${ }^{91}$. Kolejna prośbę o ułaskawienie męża skierowała Kossakowska 6 X 1952 r. Jako główne uzasadnienie podała zły stan zdrowia Stefana Kossakowskiego. 20 X 1952 r. Sąd Wojewódzki w Olsztynie zlecił więc lekarzom więziennym zbadanie stanu zdrowia osadzonego, aby dowiedzieć się, czy dalsze przebywanie $\mathrm{w}$ więzieniu nie zagraża jego życiu ${ }^{92}$. Lekarze po stwierdzeniu miażdżycy

${ }^{87}$ Obowiąek publikacji wyroku śmierci zasądzonego w trybie doraźnym przewidywał art. 14 dekretu o postępowaniu doraźnym: „O każdym wyroku śmierci należy podać do powszechnej wiadomości przez obwieszczenie w prasie lub w inny sposób z wymienieniem osoby skazanego tudzież istoty, miejsca i czasu przestępstwa" (Dz.U. 1949, nr 33, poz. 244). Informacje o procesie i wyrokach trafiły do prasy. Zob. m.in.: Sabotażyści gospodarczy z PNZ stanęli przed sadem w Olsztynie, „Trybuna Ludu”, 27 IX 1949, nr 266; Sabotażyści z PNZ przed sqdem w Olsztynie, „Dziennik Polski”, 30 IX 1949, nr 268; B. dyrektor PNZ w Olsztynie skazany na śmierć, „Życie Warszawy”, 8 X 1949, nr 277.

${ }^{88}$ Co ciekawe, ówczesne polskie ustawodawstwo nie definiowało przestępstwa „sabotażu”, choć wymieniony był w art. 3 dekretu z 13 VI 1946 r. o przestępstwach szczególnie niebezpiecznych w okresie odbudowy państwa (Dz.U. 1946, nr 30, poz. 192). Zob. A. Bosiacki, Prawo stalinowskie i jego recepcja w Polsce 1944-1955 - zarys problematyki, w: Przestepstwa sędziów i prokuratorów..., s. 46.

${ }^{89}$ AIPN Ol, SA, 9/4, Wniosek Jerzego Binzera do Sądu Apelacyjnego w Olsztynie o rewizję wyroku, 12 X 1949 r., k. 207.

90 Ibidem, Wyrok Sądu Najwyższego z dnia 14 II 1949 r. w sprawie Jerzego Binzera, Nr akt: K. 271/49, k. 301-306.

${ }^{91}$ Ibidem, Wyciag z protokołu niejawnego posiedzenia Sądu Apelacyjnego w Olsztynie, 18 IV 1950 r., k. 347.

${ }^{92}$ Ibidem, Postanowienie Sądu Wojewódzkiego w Olsztynie z 20 X 1952 r., k. 364. 
naczyń krwionośnych oraz zwyrodnienia mięśnia sercowego wydali opinię, w której zapisali, że „dalsze przebywanie [w więzieniu] wybitnie pogorszy stan zdrowia a nawet może grozić życiu"93. Przypomnijmy, że do odbycia kary pozostawało wówczas Kossakowskiemu jeszcze 11 lat. Kilka tygodni później, na podstawie ustawy amnestyjnej z 22 XI 1952 r., kara 15 lat więzienia została Kossakowskiemu złagodzona do lat 10. Jednak pogarszający się stan zdrowia Kossakowskiego sprawił, że 13 VI 1953 r. uzyskał on przerwę w wykonaniu kary na okres 6 miesięcy ${ }^{94}$.

W 1953 r. żona Kossakowskiego i jego adwokat skierowali kolejne prośby o ułaskawienie do Prokuratora Generalnego PRL. Jak uzasadniał adwokat Kossakowskiego we własnym wniosku, gdyby postępowanie sądowe nie odbyło się w postępowaniu doraźnym, najwyższa kara, która groziłaby Kossakowskiemu, mogłaby wynieść 5 lat więzienia. 21 IX 1953 r. Sąd Wojewódzki w Olsztynie zaopiniował wspomniane prośby. Uznał, że skazany zasługuje na to, aby darować mu w drodze łaski resztę nieodbytej kary. W uzasadnieniu stwierdzono m.in., że „wymiar kary - w chwili wydania wyroku właściwy - ze względu na konieczność prewencji i represji - obecnie - ze względu na upływ czasu i wzmocnienie Państwa - wydaje się być za surowy" ${ }^{95}$.

W wyniku powyższej opinii Prokurator Generalny PRL złożył do Sądu Najwyższego wniosek o rewizję nadzwyczajna w sprawie Stefana Kossakowskiego. Rozprawa rewizyjna odbyła się 29 I 1954 r. Sąd Najwyższy zmienił zaskarżony wyrok z 6 X 1949 r. w części dotyczącej Kossakowskiego i skazał go na 6 lat więzienia z zaliczeniem odbytej dotąd kary (10 XII 1948 - 13 VI 1953 r.). Orzeczoną karę złagodził o $1 / 3$ do 4 lat. W związku z zaliczeniem okresu tymczasowego aresztowania i odbytej dotąd kary uznał wymierzona karę za zakończona. W uzasadnieniu Sąd Najwyższy stwierdził, że Kossakowski nie odpowiadał za zaniedbania w ZO PNZ, gdyż „działał pod silna presją moralną wywierana przez Koziełł-Poklewskiego, którego despotyczne rządy ograniczały swobodę jego decyzji”"96.

Trzeci skazany - Jan Koziełł-Poklewski już 8 X 1949 r. zwrócił się do Bieruta z prośbą o ułaskawienie i zamianę kary śmierci na więzienie. $\mathrm{W}$ uzasadnieniu tłumaczył się brakiem złej woli, porywistym charakterem i „chorobliwym stanem psychicznym", a także tym, że w jego działaniu nie było chęci własnego zysku lub korzyści materialnej. Prośbę zakończył w następujący sposób: „Jestem jeszcze stosunkowo młodym człowiekiem [ur. w 1904 r. - R.G.] i mógłbym jeszcze pracować. Moje dotychczasowe życie przebyłem w dość

\footnotetext{
${ }_{93}$ Ibidem, Orzeczenie lekarskie o stanie zdrowia więźnia Stefana Kossakowskiego, 13 XI 1952 r., k. 368

${ }^{94}$ Ibidem, Wniosek o ułaskawienie Stefana Kossakowskiego, 13 VII 1953 r., k. 380-381.

${ }_{95}$ Ibidem, Opinia Sądu Wojewódzkiego w Olsztynie z 21 IX 1953 r., k. 392-393.

96 Ibidem, Wyrok Sądu Najwyższego w sprawie Stefana Kossakowskiego z powodu rewizji nadzwyczajnej założonej przez Generalnego Prokuratora PRL, 29 I 1954 r., k. 402-404.
} 
trudnych warunkach materialnych. Proszę uwzględnić i to, że brałem udział w powstaniu ślaskim, z którego otrzymałem odznaczenie bojowe"97.

Zgodnie z procedura prośba Poklewskiego trafiła najpierw do Sądu Apelacyjnego w Olsztynie, w którym skład orzekajacy w sprawie Poklewskiego, Kossakowskiego i Binzera miał ją zaopiniować. Posiedzenie niejawne, podczas którego rozpatrzono podanie Poklewskiego o łaskę, odbyło się $14 \mathrm{X}$ 1949 r., z udziałem sędziego Józefa Kuprowskiego ${ }^{98}$ oraz ławników Michała Sokołowskiego i Mariana Polońskiego. Co ciekawe, dwaj sędziowie ławnicy, wymienieni wyżej: Sokołowski i Poloński, wyrazili opinię, że Poklewski nie zasługuje na ułaskawienie. Stwierdzili, że jest on „świadomym wrogiem ustroju demokratycznego Polski Ludowej”, a jego zachowanie podczas procesu nie wskazywało na „chorobliwy stan psychiczny”. Poza tym wyrazili przekonanie, że Poklewski „nigdy nie będzie pożytecznym człowiekiem w społeczeństwie” ${ }^{99}$.

Odrębną opinię wydał sędzia Józef Kuprowski. Uzasadnił ją tym, że Poklewski w czasie popełniania przestępstwa „zachowywał się jak typowy furiat". Dowodem nieracjonalnego myślenia skazanego miało być zdaniem sędziego to, że „ze swoim pochodzeniem szlachecko-ziemiańskim i nazwiskiem oraz ze swoja przeszłością zapisał się do PPR", co świadczyło, że Poklewski nie działał rozsądnie, „bo człowiek rozsądny byłby się musiał liczyć z tym, że wcześniej lub później zostanie zdekonspirowany i z partii wydalony. Człowiek z jego sfery i z jego przeszłościa, jeśliby był rozumny, nie pchałby się również na odpowiedzialne stanowisko dyrektora Zarządu Okręgowego Państwowych Nieruchomości Ziemskich”. Poza tym zwrócił uwagę, że częściowa winę za niegospodarność w ZO PNZ w Olsztynie ponosili ci, którzy powierzyli „degeneratowi ze sfery ziemiańskiej” tak wysokie stanowisko. Tym samym sędzia, świadomie lub nie, odniósł się do władz partyjnych, gdyż, jak już wspomniano, kandydaturę Poklewskiego na stanowisko dyrektora ZO PNZ wysunał KW PPR i wsparł WUBP w Olsztynie.

Sędzia Kuprowski zauważył także, że za czyny przypisane Poklewskiemu, sądzone w postępowaniu zwyczajnym, a nie doraźnym, groziłaby mu kara łączna, która nie mogłaby przekroczyć 7,5 roku więzienia. Na koniec zaznaczył, że wyrok śmierci Poklewskiego „osiagną już swój cel wychowawczy w sensie odstraszenia innych od popełniania takich czynów z chwilą jego ogłoszenia na sali rozpraw i przez opublikowanie go w dziennikach i z tego tytułu nie zachodzi konieczność wykonania kary śmierci” ${ }^{100}$.

\footnotetext{
${ }^{97}$ Ibidem, Prośba Jana Koziełł-Poklewskiego o łaskę skierowana do prezydenta Bolesława Bieruta, 8 X 1949 r., k. 197.

${ }^{98} \mathrm{~W}$ związku ze zwolnieniem lekarskim, na którym przebywał sędzia Z. Tęgowski, posiedzeniu przewodniczył sędzia Józef Kuprowski.

${ }_{99}$ AIPN Ol, SA, 9/4, Opinia w sprawie ułaskawienia Jana Koziełł-Poklewskiego, $14 \mathrm{X}$ 1949 r., k. 238-239.

${ }^{100}$ Ibidem, k. 239-240.
} 
W powyższej opinii zastanawia to, że ławnicy - tzw. czynnik społeczny - postulowali zachowanie najsurowszego wymiaru kary. Wydaje się, że ich stanowisko wynikało z samej istoty, roli i znaczenia, jakie przypisała ławnikom władza komunistyczna. W składach orzekajacych reprezentować mieli interes partii rządzącej ${ }^{101}$. Poloński i Sokołowski - eksponowani działacze PZPR w Olsztynie - swoja postawą w Sądzie Apelacyjnym z jednej strony podkreślali poparcie i wierność nowej władzy i jej polityce, z drugiej prawdopodobnie realizowali wytyczne KW PZPR. Mimo bezkompromisowego stanowiska lokalnych działaczy partyjnych, Bierut 19 XI 1949 r. zdecydował się jednak ułaskawić Poklewskiego i zamienił karę śmierci na dożywotnie więzienie $^{102}$. Nie wiemy, co ostatecznie wpłynęło na jego decyzję: czy fakt włączenia się Poklewskiego po wojnie w proces budowy „nowej” Polski i jego członkostwo w PPR, czy też to, że zarówno proces, jak i publiczne ogłoszenie wyroku spełniły już swój „cel wychowawczy”.

W związku z tym, że Poklewskiego skazano dwoma wyrokami (16 IX i 6 X 1949 r.), a przestępstwa zostały popełnione przed wydaniem pierwszego wyroku, ponadto nastapiła zamiana kary śmierci na wyrok dożywotniego więzienia w drodze ułaskawienia, prokurator Sądu Apelacyjnego A. Fafara 12 I 1950 r. przesłał do tegoż sądu wniosek o wydanie wyroku łącznego ${ }^{103}$. Rozprawa odbyła się 31 III 1950 r. Sąd Apelacyjny wymierzył Poklewskiemu łączną karę dożywotniego więzienia z pozbawieniem praw publicznych

${ }^{101}$ Ławnicy po wojnie stali się elementem „walki o sądownictwo” nowej władzy. Powoływanie ich przez prezydia rad narodowych, całkowicie kontrolowane przez komunistów, pozwalało władzy na swobodny dobór składu orzekającego, a zważywszy na to, że byli obdarzeni pełnymi kompetencjami sędziowskimi, także na wydawane wyroki. Ławników powoływano już w specjalnych sądach karnych do sądzenia przestępstw popełnionych przez „zbrodniarzy faszystowsko-hitlerowskich” (dekret z 12 IX 1944 r., Dz.U. 1944, nr 4, poz. 21). Po zniesieniu sądów specjalnych dekretem z 17 X 1946 r. (Dz.U. 1946, nr 59, poz. 324) i przekazaniu spraw należących do ich właściwości sądom okręgowym, w składach orzekających również znaleźli się jeden sędzia i dwóch ławników (wyznaczonych przez prezydium WRN). Ławnicy odgrywali także ważną rolę $\mathrm{w}$ orzekaniu o czynach zabronionych w dekrecie z 16 XI 1945 r. o przestępstwach szczególnie niebezpiecznych w okresie odbudowy państwa (Dz.U. 1945, nr 53, poz. 300), w tych sprawach, które przekazano orzekaniu sądom okręgowym. Stan ten utrzymał dekret z 13 VI 1946 r. (Dz.U. 1946, nr 30, poz. 192). Z udziałem ławników odbywało się również orzekanie w trybie doraźnym (dekret z 16 XI 1945 r. o postępowaniu doraźnym, tekst jedn. z 18 V 1949 r., Dz.U. 1949, nr 33, poz. 244). Udział ławników w postępowaniu sądowym upowszechniła ustawa z 26 IV 1949 r. o zmianie prawa o ustroju sądów powszechnych (Dz.U. nr 32, poz. 237). Szerzej o roli ławników w przejmowaniu kontroli nad sądownictwem przez władze komunistyczne zob. A. Rzepliński, Sadownictwo w Polsce Ludowej, Warszawa 1989 (drugi obieg wyd.), s. 18-29.

102 AIPN Ol, SA, 9/4, Pismo dyrektora gabinetu ministra w Ministerstwie Sprawiedliwości do Sądu Apelacyjnego w Olsztynie, 25 XI 1949 r., k. 287.

${ }_{103}$ AIPN Ol, SA, 9/3-2, Wniosek prokuratora Sądu Apelacyjnego A. Fąfary o wyrok łączny dla J. Koziełł-Poklewskiego, 12 I 1950 r., k. 445. 
i obywatelskich praw honorowych na zawsze i jednoczesnym przepadkiem mienia na rzecz skarbu państwa ${ }^{104}$. Wyrok uprawomocnił się 8 IV $1950 \mathrm{r}$.

Kolejne ustawy amnestyjne z 22 XI 1952 i 27 IV 1956 r. ${ }^{105}$ doprowadziły do złagodzenia wyroku Poklewskiego. 16 XII 1953 r. Sąd Wojewódzki orzeczona Poklewskiemu karę śmierci, zamienioną na dożywotnie więzienie, złagodził do 12 lat więzienia. 26 VI 1956 r. postanowieniem Sądu Wojewódzkiego warunkowo przedterminowo zwolniono Poklewskiego z dalszego odbywania kary więzienia ${ }^{106}$, a 20 IV 1957 r., na skutek rewizji nadzwyczajnej, Sąd Najwyższy dopatrując się poważnych uchybień w rozprawie Sądu Apelacyjnego w Olsztynie, wydał wyrok uchylający poprzedni (z 6 X 1949 r.) w części dotyczącej Poklewskiego, pierwotnie skazujący go na karę śmierci. Warto w tym miejscu przytoczyć fragmenty wyroku Sądu Najwyższego:

Zasadniczy błąd byłego Sądu Apelacyjnego w Olsztynie w sprawie doraźnej Nr I.K. 12/49 polega na nieuzasadnionym należycie uznaniu, że straty Skarbu Państwa w gospodarstwach podległych Zarządowi Okręgowemu PNZ w Olsztynie - sięgające wg oceny biegłych ok. $75000000 \mathrm{zł} \mathrm{(w} \mathrm{dawnej} \mathrm{relacji)} \mathrm{były} \mathrm{spowodowane} \mathrm{umyślnie}$ wadliwa polityka personalna, prowadzona przez Jana Koziełł-Poklewskiego - jako dyrektora ZO PNZ [...]. Sąd ogólnikowo powołał się na opinię biegłych A.[ntoniego] Erdmana i B.[ernarda] Berdychowskiego, nie poddając jej, wbrew obowiązkowi - własnej ocenie. [...] Z opinii biegłych wynika przede wszystkim, że przy obliczeniu strat wyszli oni z czysto teoretycznych założeń, bez uwzględnienia warunków poszczególnych gospodarstw. Tak np. kwota ok. 55000000 zł strat w zbiorach ziemniaków została wyliczona $\mathrm{z}$ różnicy wydajności z hektara pomiędzy przewidywaną na 1948 r. wydajnością - 100 q z 1 ha, a osiagniętą 65,8 q, co w przeliczeniu na ogólną powierzchnię upraw ziemniaka i uwzględnieniu ceny za 1 q ziemniaków dało tak wielką kwotę strat. Równocześnie w tej samej opinii biegli zaznaczyli, że w 1948 r. przeciętny zbiór ziemniaków w gospodarstwach indywidualnych wyniósł 71 q z 1 ha, co wskazuje, że rok ten zaznaczył się ogólnym złym urodzajem ziemniaków w woj. olsztyńskim. Zupełnie dowolne i nie poparte żadnymi argumentami wydaje się przyjęcie przez biegłych bez uwzględnienia warunków w danym rejonie, że w gospodarstwach uspołecznionych musi być osiagnięta wydajność z 1 ha o $30 \mathrm{q}$ ziemniaków, tzn. prawie o 45\%, wyższa niż w gospodarstwach indywidualnych. [...] Ponadto biegli nie wskazali, które z tych strat i w jakiej wysokości były spowodowane działaniem oskarżonego, nie uwzględnili obiektywnych przyczyn tych strat, niezależnych od oskarżonego bądź spowodowanych przez inne osoby. Usunięcie wszystkich podniesionych wątpliwości w opinii biegłych wymaga zatem zadania biegłym odpowiednich pytań, bądź powołania innej komisji biegłych a tym samym uzupełnienia

${ }^{104}$ Ibidem, Sentencja wyroku Sądu Apelacyjnego z dnia 31 III 1950 r., sygn. akt I K.10/49, k. 454-455.

105 Ustawa z 22 XI 1952 r. o amnestii, Dz.U. 1952, nr 46, poz. 309; Ustawa z 27 IV 1956 r. o amnestii, Dz.U. 1956, nr 11, poz. 57.

106 AIPN Ol, SA, 9/3-2, Postanowienie Sądu Wojewódzkiego w Olsztynie z 16 XII 1953 r., k. 469-470; ibidem, Postanowienie Sądu Wojewódzkiego w Olsztynie w przedmiocie zastosowania wobec J. Koziełł-Poklewskiego ustawy amnestyjnej z 27 IV 1956, 5 VI 1956 r., k. 472-473; ibidem, Postanowienie Sądu Wojewódzkiego w Olsztynie z dnia 26 VI 1956 r., k. 491. 
przewodu sądowego. Wyżej omówiona błędna ocena istotnych dla sprawy okoliczności faktycznych, na których wyrok w sprawie I.K. 12/49 został oparty, wymaga przeto uchylenia tego wyroku ${ }^{107}$.

Wyrok Sądu Najwyższego z 1957 r. w poważnym stopniu obnażył błędy i nieprawidłowości, jakich dopuścił się Sąd Apelacyjny w Olsztynie podczas procesu zakończonego 6 X 1949 r. Zgromadzone w sprawie materiały nie dawały podstaw do wniosków wysuniętych przez sąd, że straty w przedsiębiorstwie były spowodowane zaniedbaniami oraz umyślną i błędną polityką personalna prowadzona przez Jana Koziełł-Poklewskiego i jego współpracowników. Poza tym wbrew obowiązkowi sędziowie nie poddali własnej ocenie opinii biegłych, wykazujacych straty w oparciu o „czysto teoretyczne założenia”. Sędziowie działali więc na przekór regule sztuki procesu sądowego. Nie ma wątpliwości, że nie tyle wynikało to $\mathrm{z}$ niefachowości składu orzekającego, co z celowego działania sędziego i ławników, którzy mieli do wykonania określone zadanie: dobrze odegrać rolę w procesie pokazowym, będącym swoistym publicznym spektaklem, i posadzonych na ławie oskarżonych surowo ukarać jako sabotażystów i wrogów „Polski Ludowej”. Trudno bowiem wyobrazić sobie, że skład orzekający nie zdawał sobie sprawy z tego, że zarzucane kierownictwu ZO PNZ w Olsztynie wielomilionowe straty, które wynikać miały z niższych od zakładanych zbiorów, stanowiły skutek niesprzyjających warunków atmosferycznych, co było zreszta zjawiskiem powszechnym w skali całego województwa, także w sektorze indywidualnym rolnictwa.

Dodajmy, że proces olsztyńskiego kierownictwa PNZ wpisywał się w pewna ogólnokrajową sekwencję wydarzeń zmierzających do „oczyszczenia” PNZ $\mathrm{z}$ „elementów niepożądanych”. Był drugim głośnym procesem wytoczonym pracownikom zajmującym kierownicze stanowiska w PNZ. Przypomnijmy, że już 3 IX 1948 r. Wojskowy Sąd Rejonowy w Szczecinie wydał wyroki skazujące dyrektora ZO PNZ w Koszalinie Władysława Czarneckiego i jego sześciu współpracowników za spowodowanie strat wynoszących ponad $60 \mathrm{mln}$ zł. Czarneckiemu wymierzono karę śmierci, a pozostałym - kary od 4 do 15 lat więzienia. Na skutek późniejszych rewizji Najwyższy Sąd Wojskowy złagodził zasądzone kary, a Czarneckiemu zamieniono karę śmierci na 15 lat więzienia. W 1957 r. w wyniku rewizji nadzwyczajnej Sąd Najwyższy wszystkich uniewinnił ${ }^{108}$. Już w trakcie przygotowywania procesu olsztyńskiego uderzono

107 Ibidem, Wyrok Sądu Najwyższego z 20 IV 1957 r. w sprawie Jana Koziełł-Poklewskiego, sygn. akt. III.K.Rn. 333/57, k. 512-513.

108 Zob. Z. Romanow, Proces Zarzadu Okregu Państwowych Nieruchomości Ziemskich w Koszalinie w 1948 roku, ,Zapiski Historyczne” 2017, t. LXXXII, s. 85-106; Proces o wielomilionowe nadużycia w Państwowych Nieruchomościach Ziemskich, „Dziennik Bałtycki”, 23 VIII 1948, nr 232, s. 1; Skazani w pamiętnym procesie pracowników koszalińskiego Zarzadu Okręgu PNZ zrehabilitowani, „Głos Koszaliński”, 28 I 1957, nr 24, s. 1, 3; E. Kłoczowski, op. cit., s. 72; T. Czaplicki, op. cit., s. 329-330. 
także w centralę instytucji. W 1949 r. aresztowano kierownictwo ZC PNZ w Poznaniu: dyrektora Witolda Maringego, zastępce dyrektora Lucjusza Kempistego, dyrektora Działu Badań i Planowania Władysława Englichta, dyrektora Działu Rolnego Ludwika Slaskiego, inspektora ZC PNZ Andrzeja Potworowskiego, dyrektora Działu Zaopatrzenia i Zbytu Feliksa Sommera i inspektora ZC PNZ Kazimierza Paparę, którym w 1951 r. wytoczono proces pokazowy. Ponadto w oddzielnych procesach sądzeni byli kierownik Wydziału Organizacyjnego (później Rolnego) Zdzisław Lechnicki i szef Inspektoratu Generalnego Tadeusz Krzyżanowski. Kary dożywotniego więzienia otrzymali: Maringe, Englicht i Papara. Kempisty i Lechnicki zostali skazani na 15 lat więzienia, Slaski, Potworowski i Sommer - na 10 lat więzienia. Sommer i Krzyżanowski zmarli w więzieniu. W 1956 r. wszyscy zostali uniewinnieni ${ }^{109}$.

Powyższe procesy, jak i proces kierownictwa ZO PNZ w Olsztynie, sa jeszcze jednym dowodem na to, że prawo w państwie stalinowskim służyło nie obywatelom, lecz partii rządzącej, a składy orzekające stały się poręcznym narzędziem wydającym wyroki „po myśli” ówczesnej władzy, tzn. wpisujące się w teorie przezeń wysuwane i obraną linię polityczna, zakładającą fizyczna bądź więzienną eliminację faktycznych i domniemanych oponentów nowego systemu oraz gruntowne oczyszczanie społeczeństwa i instytucji państwowych z „niebezpiecznych elementów”. Służyć temu miały dyspozycyjne sądy wymierzające surowe kary, z kara śmierci włącznie ${ }^{110}$.

W przypadku procesu olsztyńskiego ciekawe było to, że władze nie wahały się zastosować „środków sądowych” do wyeliminowania w pełni dyspozycyjnego dyrektora ZO PNZ i jego współpracowników. Jednak w tym wypadku, tak jak w przypadku procesu koszalińskiego i procesu przygotowywanego kierownictwu ZC PNZ w Poznaniu, jak się wydaje, decydujące znaczenie miało pochodzenie ziemiańskie Poklewskiego i Binzera, a także przedwojenna wojskowa przeszłość Kossakowskiego, co wyraźnie sytuowało oskarżonych w gronie środowisk zdefiniowanych przez władzę jako wrogie wobec nowego państwa i systemu. Aresztowanie i skazanie ich wpisywało się w linię partii, zgodnie z która władza, segregując Polaków według powyższego kryterium, eliminowała z życia społecznego osoby o „nieodpowiednim” pochodzeniu bądź życiorysie. Tak zdefiniowanych „wrogów”, którym przypisano świadome dopuszczanie się aktów sabotażu, należało publicznie napiętnować oraz trwale bądź na długie lata wyrzucić poza nawias życia społecznego.

Proces kierownictwa ZO PNZ w Olsztynie, w którym dyspozycyjni sędzia i ławnicy nie bacząc na obiektywne okoliczności, świadomie posługując się

\footnotetext{
109 Szerzej zob. T. Osiński, op. cit., s. 240-258; L. Slaski, Lata wykreślone z życia. Proces polityczny $i$ więzienia PRL, Kraków 1992.

${ }^{110} \mathrm{O}$ znaczeniu kary śmierci w polityce karnej państwa w pierwszych latach powojennych zob. P. Kładoczny, Kara śmierci jako wyktadnik polityki karnej państwa w latach 1944-1956, w: Przestępstwa sędziów i prokuratorów..., s. 67-84.
} 
nierzetelnymi, budzącymi wątpliwości opiniami biegłych, nie wahali się uznać oskarżonych za winnych, a jednego z nich jednogłośnie skazać na karę śmierci, pozwala zakwalifikować wyrok Sądu Apelacyjnego w Olsztynie z 6 X 1949 r. do kategorii wyroków noszących znamiona „zbrodni sądowej”, niezależnie od późniejszych jego zmian.

\section{Streszczenie}

Po włączeniu ziem poniemieckich po II wojnie światowej do Polski wielkie majątki ziemskie zostały przejęte w administrację państwową początkowo przez urzędy ziemskie, a od $1946 \mathrm{r}$. przez Państwowe Nieruchomości Ziemskie (PNZ) (majątki powyżej 100 ha). Z czasem PNZ przejęły także majątki na tzw. ziemiach dawnych (powyżej 50 ha). W PNZ trzon kadry kierowniczej, zarówno w centrali - Zarządzie Centralnym w Poznaniu, jak i w zarządach okręgowych, stanowili wywłaszczeni ziemianie. Ten fachowo przygotowany personel został zatrudniony w okresie pełnienia funkcji ministra rolnictwa i reform rolnych przez Stanisława Mikołajczyka.

Ziemianie w administracji majątków państwowych nie byli akceptowani przez komunistów. Po odsunięciu Mikołajczyka przystapiono do stopniowego przejmowania kontroli nad przedsiębiorstwem i „oczyszczenia” kadrowego PNZ, połączonego z akcją propagandową mająca wykazać złą wolę struktur kierowniczych przedsiębiorstwa i świadomą działalność ziemian na szkodę państwa. Użyto do tego celu funkcjonariuszy Urzędu Bezpieczeństwa Publicznego, którzy zajęli się inwigilacją centrali i lokalnych struktur PNZ. Ich głównym celem było zgromadzenie materiału obciążającego, który miał stać się podstawą do wytoczenia kadrze zarządzajacej przedsiębiorstwem procesów pokazowych o sabotaż.

Niezwykle istotną rolę odegrały także, podporządkowane władzy i dyspozycyjne, sądy, które wymierzały oskarżonym bardzo surowe kary, opierając się na wątpliwym materiale dowodowym. Proces kierownictwa olsztyńskiego Zarządu Okręgowego PNZ przed Sądem Apelacyjnym w Olsztynie, podczas którego dyrektor biura został skazany w 1949 r. na karę śmierci, w świetle błędów i nieprawidłowości wytkniętych przez Sąd Najwyższy w rewizji nadzwyczajnej w 1957 r., zakwalifikować można do kategorii wyroków noszących znamiona „zbrodni sądowej”.

\section{Surveillance and Trial of the Regional Board Management of the State Land Properties in Olsztyn}

When, after World War Two, the former German lands were incorporated into Poland, great landed estates were appropriated by the state administration - initially by land offices, and from 1946 on, by a special agency called the State Land Properties (Państwowe Nieruchomości Ziemskie) (over $100 \mathrm{ha}$ ). In time, the State Land Properties took over estates in the so-called Old-Polish Lands (over 50 ha). The key officials of the State Land Properties - both in its head office in Poznan, and in regional offices - were expropriated landowners. They formed the personnel with expert knowledge, employed under Agriculture Minister and Agrarian Reforms Stanisław Mikołajczyk.

Communists did not accept landowners in the management of state-owned lands. After Mikołajczyk was dismissed, the State Land Properties was gradually taken over and its staff "purged", simultaneously with a propaganda campaign that was to demonstrate the "ill will" of the management of the agency and their purposeful activity to the detriment of the state. To this end, functionaries of the Public Security Office mounted surveillance 
of both the head office in Poznan and its regional offices. Their main purpose was to collect inculpatory material that was to serve as the basis to institute legal proceedings against the managerial staff on sabotage charges and mount show trials against them.

A crucial role was also played by courts - subordinated to the state authorities and a tool in their hands - who passed highly severe sentences on the basis of doubtful evidence. A trial of the management of the Olsztyn Regional Office of the State Land Properties before the Appellate Court in Olsztyn, which ended in 1949 with the death penalty for the director of the agency, in light of errors and gross incorrectness pointed out by The Supreme Court during the extraordinary appeal in 1957, could be regarded as the "judicial crime".

\section{Bibliografia}

Bosiacki A., Prawo stalinowskie i jego recepcja w Polsce 1944-1955 - zarys problematyki, w: Przestepstwa sędziów i prokuratorów w Polsce lat 1944-1956, red. W. Kulesza, A. Rzepliński, Warszawa 2001, s. 39-47.

Czaplicki T., Szlacheckie ostatki. Dwudziestowieczna opowieść polskiego ziemianina, Warszawa 2000.

Duda H., Państwowe Nieruchomości Ziemskie w Opolu (1946-1949). Zarys monograficzny, Opole 2006.

Dudek A., Paczkowski A., Kadry organów bezpieczeństwa, w: Czekiści. Organy bezpieczeństwa w europejskich krajach bloku wschodniego 1944-1989, red. K. Persak, Ł. Kamiński, Warszawa 2010, s. 417-424.

Dziurzyński P., Osadnictwo rolne na Ziemiach Odzyskanych, Warszawa 1983.

Gieszczyński W., Majatki ziemskie na Warmii i Mazurach pod sowiecka administracja wojskowa (1945-1948), w: Między historia politycznq a społecznq, red. J. Gołota, Pułtusk-Olsztyn-Ostrołęka-Warszawa 2014, s. 287-303.

Golon M., Majatki ziemskie na Ziemiach Odzyskanych pod radzieckq administracja wojskowa $w$ latach 1945-1950, w: Wtadze komunistyczne wobec Ziem Odzyskanych po II wojnie światowej, red. S. Łach, Słupsk 1997, s. 279-300.

Gross R., Okręg Mazurski w świetle materiałów Wojewódzkiego Urzędu Ziemskiego w Olsztynie (marzec-maj 1945), „Echa Przeszłości” 2016, nr 17, s. 187-210.

Kładoczny P., Kara śmierci jako wyktadnik polityki karnej państwa w latach 1944-1956, w: Przestęstwa sędziów i prokuratorów w Polsce lat 1944-1956, red. W. Kulesza, A. Rzepliński, Warszawa 2001, s. 67-84.

Kłoczowski E., Moja praca w Państwowych Nieruchomościach Ziemskich w Poznaniu (1946-1949), Poznań 1996.

Lityński A., Na drodze ku nowej procedurze karnej: o postepowaniu przygotowawczym $w$ latach 1943-1950, w: Przestęstwa sędziów i prokuratorów w Polsce lat 1944-1956, red. W. Kulesza, A. Rzepliński, Warszawa 2001, s. 49-66.

Łukaszewicz B., Polskie Stronnictwo Ludowe na Warmii i Mazurach w latach 1945-1947, Olsztyn 1991.

Łukaszewicz B., Wojskowy Sad Rejonowy w Olsztynie 1946-1955. Szkice do monografii, Olsztyn 2000.

Nadolski M., Kwestia chtopska $w$ polityce stronnictw robotniczych $i$ ludowych $w$ Polsce w latach 1941-1947, Warszawa 1990.

Osiński T., „Klika obszarnicza”. Ziemianie w polityce personalnej Państwowych Nieruchomości Ziemskich (1946-1949), „Pamięć i Sprawiedliwość” 2012, nr 2, s. 229-259.

Rogala W., Działalność Państwowych Nieruchomości Ziemskich (1946-1949), „Rocznik Muzeum Rolnictwa w Szreniawie" 1972, t. V. 
Romanow Z., Proces Zarzqdu Okręu Państwowych Nieruchomości Ziemskich w Koszalinie w 1948 roku, „Zapiski Historyczne” 2017, t. LXXXII, s. 85-106.

Romanowska E., Karzace ramie sprawiedliwości ludowej. Prokuratury wojskowe w Polsce w latach 1944-1955, Warszawa 2012.

Rzepliński A., Sadownictwo w Polsce Ludowej, Warszawa 1989 (drugi obieg wyd.).

Szwagrzyk K., Prawnicy czasu bezprawia. Sędziowie i prokuratorzy wojskowi w Polsce 1944-1956, Kraków-Wrocław 2005.

Ziemba Z.A., Prawo przeciwko społeczeństwu. Polskie prawo karne w latach 1944-1956, Warszawa 1997.

Biog r a m: Radosław Gross - dr; zatrudniony w Instytucie Historii i Stosunków Międzynarodowych Uniwersytetu Warmińsko-Mazurskiego w Olsztynie. Zainteresowania badawcze: historia społeczna i gospodarcza PRL, dzieje Warmii i Mazur po II wojnie światowej. Autor monografii: Powszechna Organizacja „Stużba Polsce” w województwie olsztyńskim w latach 1948-1955 (Olsztyn 2011); Lidzbark Warmiński w latach 1975-1989, w: Historia Lidzbarka Warmińskiego, t. II, cz. 2, red. K. Mikulski, E. Borodij (Lidzbark Warmiński 2014, s. 11-224); Rolnictwo i polityka rolna na Warmii i Mazurach (1945-1956). Wybór źródet, zebrał i opracował R. Gross (Olsztyn 2017). E-mail: radoslaw.gross@uwm.edu.pl. 